\title{
Reasons for overwinter declines in age-1+ brook trout populations (Salvelinus fontinalis) in Appalachian headwater streams
}

Jeremy J. Webster

West Virginia University

Follow this and additional works at: https://researchrepository.wvu.edu/etd

\section{Recommended Citation}

Webster, Jeremy J., "Reasons for overwinter declines in age-1+ brook trout populations (Salvelinus fontinalis) in Appalachian headwater streams" (2004). Graduate Theses, Dissertations, and Problem Reports. 2053.

https://researchrepository.wvu.edu/etd/2053

This Thesis is protected by copyright and/or related rights. It has been brought to you by the The Research Repository @ WVU with permission from the rights-holder(s). You are free to use this Thesis in any way that is permitted by the copyright and related rights legislation that applies to your use. For other uses you must obtain permission from the rights-holder(s) directly, unless additional rights are indicated by a Creative Commons license in the record and/ or on the work itself. This Thesis has been accepted for inclusion in WVU Graduate Theses, Dissertations, and Problem Reports collection by an authorized administrator of The Research Repository @ WVU. For more information, please contact researchrepository@mail.wvu.edu. 


\title{
Reasons for Overwinter Declines in Age-1+ Brook Trout Populations (Salvelinus \\ fontinalis) in Appalachian Headwater Streams
}

\author{
Jeremy J. Webster
}

\author{
A Thesis \\ Submitted to \\ at \\ West Virginia University \\ In partial fulfillment of the requirements \\ for the degree of \\ Master of Science \\ In \\ Wildlife and Fisheries Resources
J. Todd Petty, Ph.D.
Stuart A. Welsh, Ph.D.
Mary Beth Adams, Ph.D. \\ Kyle J. Hartman, Ph.D., Chair
}

The College of Agriculture, Forestry and Consumer Sciences

Wildlife and Fisheries Program of the Division of Forestry

$$
\begin{gathered}
\text { Morgantown, West Virginia } \\
2004
\end{gathered}
$$

Keywords: Brook Trout, Body Composition, Bioelectrical Impedance Analysis, Winter, Angling, Harvest 


\section{$\underline{\text { Abstract }}$ \\ Reasons for Overwinter Declines in Age-1+ Brook Trout Populations (Salvelinus fontinalis) in Appalachian Headwater Streams \\ Jeremy J. Webster}

Brook trout (Salvelinus fontinalis) in the Appalachian Mountains often inhabit low production streams that likely limit growth. Declines in populations following winter have been noted, but the cause is unclear; possible causes include overwinter starvation and angling. The objectives of this study were to: 1) examine relative changes in body composition of brook trout as they fluctuate throughout the year, and to identify critical periods of survival to determine if brook trout reach critical levels of resource depletion over winter, and 2) evaluate whether angler harvest affects brook trout populations in spring in headwater streams. We used Bioelectrical Impedance Analysis (BIA) to estimate body composition of trout. Percent protein increased over winter in fish from 5 of 6 streams, while percent fat decreased in fish from 4 of 6 streams, though neither appeared to approach critical levels for trout. Neither fat nor proteins decreased significantly in brook trout during a simulated winter experiment over nine weeks. Field BIA estimates indicated that brook trout are unlikely to reach critical levels of resource depletion over winter. Anglers that indicated a preference for native brook trout had a mean catch of 4.5 trout per fishing trip, and this group preferred keeping trout as small as 7.1 inches on average. Motion-activated cameras indicated a range of angling effort on all streams that could represent a significant source of mortality. We conclude that high 
angler effort likely leads to a decrease in the number of large brook trout present in the study streams. 


\section{$\underline{\text { Acknowledgements }}$}

I would like to thank my graduate committee members Dr. Kyle J. Hartman, Dr. J. Todd Petty, Dr. Stuart A. Welsh, and Dr. Mary Beth Adams. Immense gratitude goes to Jon Niles, Dr. Keith Cox, Dr. John Sweka, Marisa Logan, Ben Lenz, Cindy Sanders, Missy Gamber, Ryan Utz, Meredith Withers, and Chris Horn for their tireless help in the

field. Special thanks go to Dr. George Seidel and Dr. John Sweka for all of their statistical support. Special dedication goes to all of my friends ("Tot Spot") and family who I have neglected in the pursuit of this degree. Funding for this project was provided by the USDA Forest Service, MeadWestvaco Corporation, and the West Virginia Division of Natural Resources. 


\section{$\underline{\text { Table of Contents }}$}

Chapter 2. List of Tables............................................................................................... vi

Chapter 2. List of Figures ........................................................................................... vii

Chapter 2. List of Figures ctd. .................................................................................... vii

Chapter 3. List of Tables....................................................................................... ix

Chapter 3. List of Figures ………………………………........................................ $\mathrm{x}$

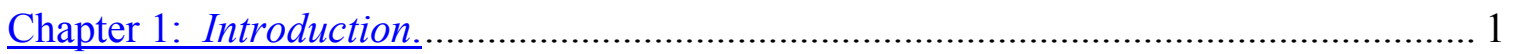

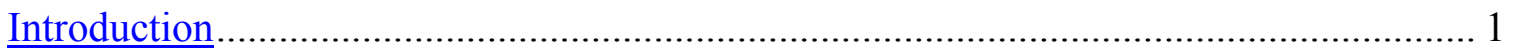

Seasonal Effects on Body Composition ...................................................................... 2

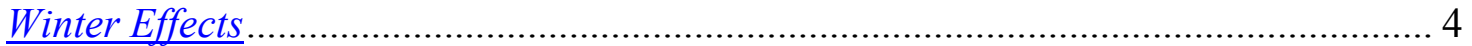

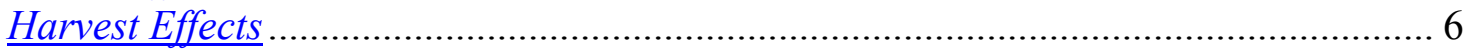

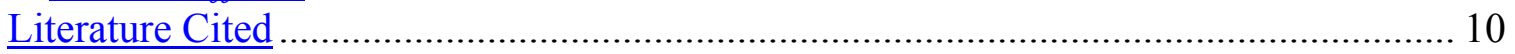

Chapter 2. Investigation of possible seasonal population bottlenecks in brook trout (Salvelinus fontinalis) in Central Appalachian headwater streams. ............................... 13

Abstract

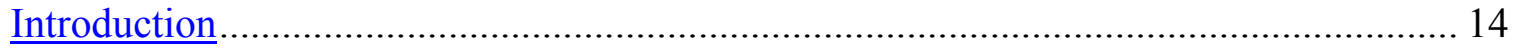

Study Area

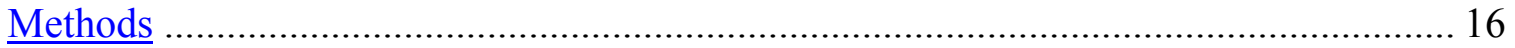

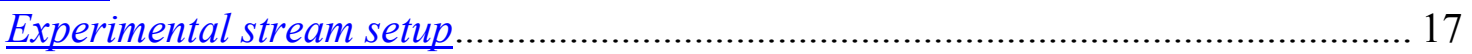

Bioelectrical Impedance Analysis........................................................................ 18

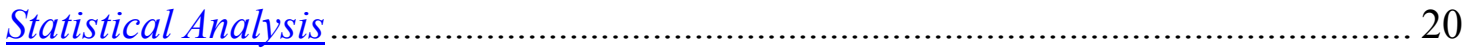

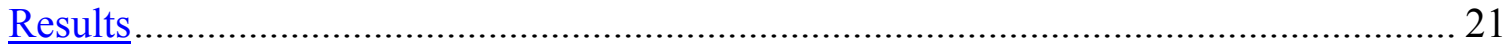

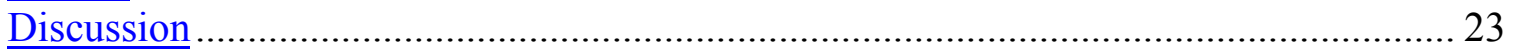

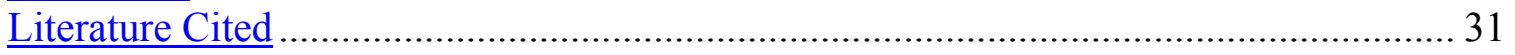

Chapter 3. Can Angler Harvest Affect Brook Trout Populations in West Virginia Headwater Streams? ..................................................................................................... 47

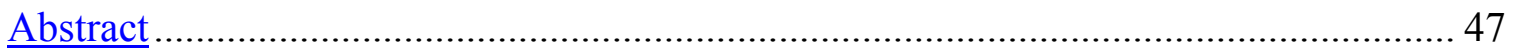

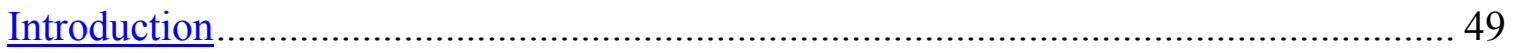

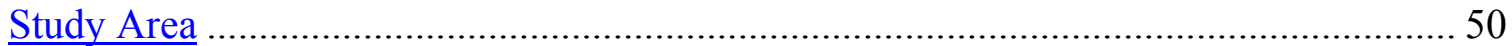

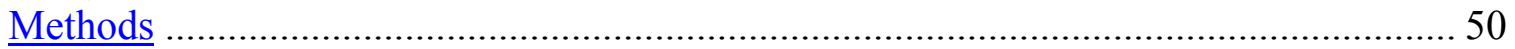

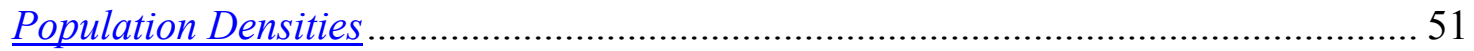

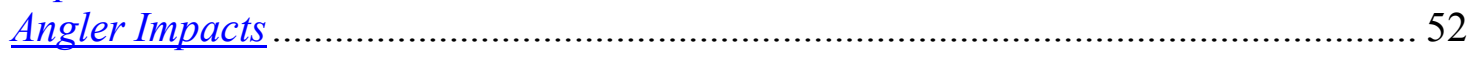

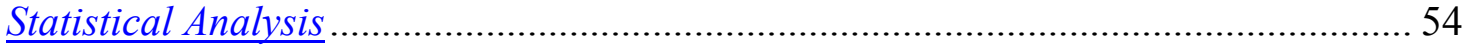

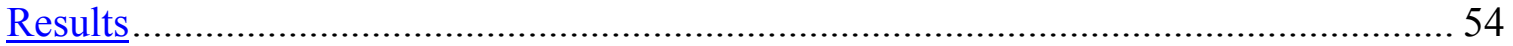

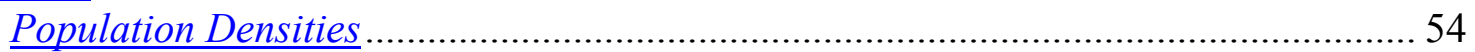

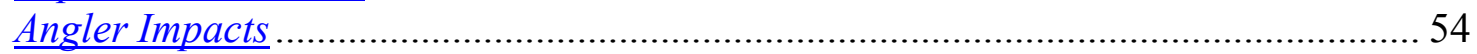

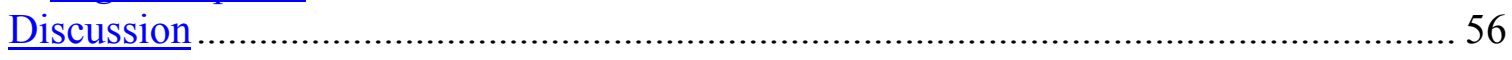

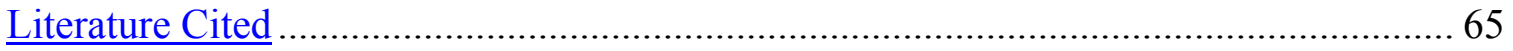




\section{Chapter 2. List of Tables}

Table 1. Seasonal data for selected proximate body composition variables of brook trout using Bioelectrical Impedance Analysis for the six study streams. Results of statistical testing between seasons at each location are shown as the significance levels between the appropriate variables........................................................ 34

Table 2. Pre- and post-spawning mean body composition data for male (M) and female (F) brook trout in all streams combined for September/ October and November/ December sampling periods. Results of statistical testing between seasons at each location are shown as the significance levels between the appropriate variables..........35 


\section{Chapter 2. List of Figures}

Figure 1. Temperature data for four streams from May 2003 to January and February 2004. Note: Temperature loggers were lost for Rocky and Elklick Runs.

Figure 2. Calculated regression lines of percent body composition of brook trout as it relates to total length. Note: All were significant at the alpha $=0.05$ level (all streams and seasons combined)

Figure 3. Mean population estimates of stock-size brook trout from all streams combined. Error bars represent $95 \%$ confidence intervals calculated by Program 2Capture. .38

Figure 4. Relationship between actual weight $(\mathrm{g})$ of brook trout and weight predicted by Bioelectrical Impedance Analysis of all fish analyzed in this study. ...

Figure 5. Seasonal mean percent proximate body composition values of brook trout greater than $130 \mathrm{~mm}$ total length for the six study sites combined. Note: June November/ December sampled in 2003, and February/ March in 2004

Figure 6. Seasonal mean percent proximate body composition values of brook trout greater than $130 \mathrm{~mm}$ total length for the six study sites. Note: June - November/ December sampled in 2003, and February/ March in 2004.

Figure 7. Seasonal mean percents of protein, fat, and ash weights of the total dry weight of brook trout greater than $130 \mathrm{~mm}$ total length (all streams combined). Note: June November/ December sampled in 2003, and February/ March in 2004

Figure 8. Means of estimated body composition weights of experimental (Week 1, Week 9) vs. wild (November/ December, February/ March) brook trout determined using Bioelectrical Impedance Analysis. Trout from all streams combined were used to calculate means of wild brook trout for the two sampling periods shown, and trout in tanks A and B were similarly combined for each week. Error bars represent $95 \%$ confidence intervals

Figure 9. Means of protein and fat weights for brook trout in simulated winter experiment determined using Bioelectrical Impedance Analysis. Note: Trout in each tank were combined to generate means.................................................. 44 


\section{Chapter 2. List of Figures ctd.}

Figure 10. . Mean fat weights of brook trout from pre- (November/ December) and post(February/ March) winter sampling periods. Black line represents critical level of fat (0.2 g) that may lead to mortality for salmonids (juvenile rainbow trout 120-142 mm TL, Oncorhynchus mykiss, Simpkins et al. 2003a). Error bars represent 95\% confidence intervals. CR - Clubhouse Run, PR - Poca Run, WR - Whites Run, ER - Elklick Run, RDR - Red Run, ROR - Rocky Run.

Figure 11. Mean total energy (kJ) content of stock-size brook trout for pre- (November/ December) and post- (February/ March) winter sampling periods. Error bars represent 95\% confidence intervals. CR - Clubhouse Run, PR - Poca Run, WR - Whites Run, ER

- Elklick Run, RDR - Red Run, ROR - Rocky Run.................................46 


\section{Chapter 3. List of Tables}

Table 1. Averages of answers to select questions from angler surveys. Note: Standard error of each mean shown in parentheses. \% anglers fishing headwater streams are actual

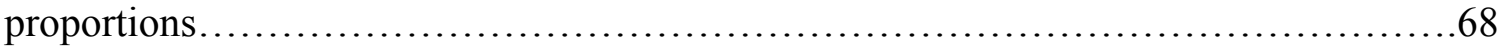

Table 2. Estimated brook trout catch for each stream based on the number of anglers photographed. Total catch calculated by multiplying number of anglers by the mean brook trout caught per trip of native fishermen based on angler surveys. Catch per 100 meters determined by dividing total catch by total stream length.......................69 


\section{Chapter 3. List of Figures}

Figure 1. Changes in brook trout population abundances over winter of stock-size $(>130$ mm TL) trout as calculated by Program 2CAPTURE. Note: The first histogram of each pair was sampled in November/ December 2003 and the second in February/ March 2004. CR - Clubhouse Run, PR - Poca Run, WR - Whites Run, ER - Elklick Run, RDR

- Red Run, ROR - Rocky Run.............................................70

Figure 2. Example of angler questionnaire asked of all 96 anglers in this study........71

Figure 3. Relationship between population decline in the number of stock-size brook trout from post-spawning (November/ December) to spring (February/ March) and harvest (\# of brook trout kept by anglers) per $100 \mathrm{~m}$ of stream. * Red Run is a special regulations, catch-and-release only stream and harvest is assumed to be zero.............72 


\section{Chapter 1.}

\section{Introduction}

Brook trout (Salvelinus fontinalis) are indigenous to eastern North America and are the only member of the Salmonidae family native to West Virginia. These fishes are found throughout the state, but native brook trout are confined to lower order streams (typically $1^{\text {st }}-3^{\text {rd }}$ order). Brook trout in this region rarely live past 4 years. The age structure of a these trout populations typically exhibits four age groups in northern populations (Hunt 1974). Southern populations of the fish rarely exceed $250 \mathrm{~mm}$ and three years of age (Whitworth and Strange 1983). Brook trout spawn in the fall when females build redds in gravelly substrate and drop their eggs simultaneously as the males release their milt (sperm) (Karas 2002).

Brook trout prefer colder water temperatures than brown (Salmo trutta) and rainbow trout (Oncorhynchus mykiss), with which they often share the same waters in the Central Appalachian mountains. While brook trout prefer deeper, colder pools, they may be found in a variety of habitats. However, brook trout have been extirpated from many streams in West Virginia due to anthropogenic effects. Humans have left long-lasting scars including acid mine drainage, acid deposition, and sedimentation due to poor land use practices. 


\section{Seasonal Effects on Body Composition}

Seasonal changes in body composition of salmonids often reflect changes in the surrounding environment. These changes include abiotic factors such as temperature, flow, and photoperiod, and biotic factors including food availability, competition, and predation. Love (1970) purports these physiological changes may also be a function of fish following an "inner rhythm" or "biological clock" controlled by the endocrine system. Thus, it may be a combination of biology and environment that drive physiological changes in brook trout throughout the year.

Growth is often greatest in spring months because food becomes more available, and water temperatures increase. Both food and temperature can influence the growth rate of trout (Elliott et al. 1995, Elliott and Hurley 1997). In particular, spring growth is attributed to a dramatic increase in lipid content seen during these months (Berg and Bremset 1998, Cunjak and Power 1986). The increase in lipid content is likely related to the increase in food consumption by brook trout during the spring months (Cunjak et al. 1987). Relative contributions to increases in body constituents may also be attributed to nutrition of the prey the fish eat. The condition factor of brook trout also increases dramatically from winter to spring and is highest in the spring (Cunjak et al. 1987, Cunjak and Power 1987). Similarly, proteins increase during the spring months (Cunjak and Power 1986). As a result, brook trout may use the spring season with its abundance of food and cooler water temperatures, to replenish lacking body constituents.

In summer, brook trout in the Central Appalachian mountains must overcome increased (and occasionally critical) water temperatures and decreased water flows. One typical behavioral response to these problems is to move to areas of refugia, where 
temperatures are cooler and the volume of water is higher (i.e. pools, groundwater seeps). Prey is still abundant this time of year, though it may shift towards the greater importance of terrestrial invertebrates (Bridcut and Giller 1995, Elliott 1967, Sagar and Glova 1988). Body contents of lipids and proteins again increase (though not as dramatically compared to spring) this time of year in brook trout populations (Cunjak and Power 1986, Shearer et al. 1994), though possibly for different reasons than spring. In late summer lipid and protein stores are mobilized in mature trout for gamete production.

Major changes in proximate body composition occur in fishes at important life cycle periods. These include first feeding, smoltification (anadromous fishes), and sexual maturation (Shearer et al. 1994). These events are associated with periods of rapid tissue building, high energy demands, and transfer of somatic material to the gonads (Shearer et al. 1994). Trout are unable to produce gametes until a minimum lipid threshold level is reached (Shearer et al. 1994). This may be from 1 to 3 years of age in Central Appalachian brook trout (Jenkins and Burkhead 1993). At this minimum threshold level, the trout has sufficient energy to produce gametes, and still meet minimum metabolic requirements for the spawning period. As trout spawn, they release sperm or eggs, and thus we might expect a decrease in energy resources due to loss of lipids, but the data from the literature are mixed. Cunjak and Power (1986) showed that lipids increased over the spawning months in one population of brook trout, but decreased in another. A similar pattern was seen in Atlantic salmon (Salmo salar), with lipids increasing after spawning in one group and decreasing in another (Shearer et al. 1994). This variability is likely due to differing individuals and populations of fish spawning at different times 
throughout the fall. Upon completion of spawning, brook trout must acclimate to rapidly decreasing water temperatures typical of this time of year.

\section{Winter Effects}

Winter may be considered the critical period in life for stream salmonids (Whitworth and Strange 1983). During this season brook trout must rely on stored energy reserves to survive harsh conditions (Keast 1968). Several factors contribute to decreasing energy levels over these critical months, including extremely low water temperatures, depressed feeding, decreased water flow, and possible habitat alterations (Needham et al.1945). Elliott (1976) found that salmonids will stop growing new tissue when water temperatures decrease to $4-7^{\circ} \mathrm{C}$. Similarly, Cunjak and Power (1987) concluded that growth is negligible in stream resident trout in winter. Evidence has shown that brook trout decrease in weight and condition factor as the winter months pass (Cunjak et al. 1987). Though trout are not likely to increase in size over winter, they still must possess enough energy to cover the costs of metabolism and this can become exceedingly difficult for trout.

The winter period is especially severe for mature trout that may have lost much of their energy reserves after spawning in the fall. Decreases in lipid levels are more rapid in early winter compared to that of late winter (Berg and Bremset 1998). Males may also find themselves at more of a disadvantage than females. Hutchings et al. (1999) concluded that lipid reductions were higher in males in winter than females. This reduction in lipids following spawning can be especially critical in temperate climes like West Virginia because water temperatures will often decrease most rapidly in early winter. This rapid decline in water temperatures makes it difficult for brook trout to 
acclimate quickly and can leave them in poor condition upon entering the winter (Cunjak et al. 1987). Similarly, Cunjak and Power (1987) showed that body condition of brown and brook trout decreased early in winter, and remained low throughout the rest of the season.

Other salmonid species exhibit similar reductions in body condition and physiological reserves in winter. Both lipid and protein levels decreased over the winter in Atlantic salmon (Berg and Bremset 1998, Shearer et al. 1994). A trout that enters winter with too little body reserves may face death because there is little chance for a trout to recover reserves once it has reached a critical level of depletion. While feeding occurs in winter, it may occur at a depressed level because there is less food available. In addition, the prey may be of lower nutritional value (Cunjak et al. 1987). Compounding this is the difficulty of digesting and assimilating the food in cold water. Gastric evacuation rates of brook trout are known to be significantly lower in colder temperatures (Sweka et al. 2004), meaning these fish feed less because it takes longer to empty their stomachs. As mentioned earlier, for brook trout to survive in winter, energy stores must be ample enough to offset metabolic costs because metabolic demands may exceed energy intake during this season. As a result lipid levels in brook trout often decrease in winter as the energy stores are used up (Cunjak and Power 1986). While mortality does occur in brook trout populations in winter, these populations still manage to persist.

Winter is considered the major period of brook trout mortality much of it believed to be due to depletion of energy stores (Whitworth and Strange 1983). Although these stores decrease, trout may have enough reserves to survive the winter. Cunjak et al. (1987) found that brook trout populations in winter exhibited stomach fullness 
comparable to that of summer feeding. Winter feeding does not necessarily translate to healthy fish because of nutrition and assimilation difficulties due to prey type and colder temperatures, although in some populations the feeding is enough to cover metabolic costs. Cunjak and Power (1987) discovered that some trout exhibited stomach fullness of over 50\% (although observed gastric evacuation rates were low), and had more than enough energy to cover the costs of metabolism. In a similar study, lipid content in trout did not significantly decrease between the October and June sampling periods in Salvelinus alpinus (Cunjak and Power 1986). Further, the authors reported that although energy is depleted over winter, it was not serious enough to affect mobilization of protein stores. These protein stores are only used after lipid reserves have been exhausted (Love 1970). In this same population, surviving trout showed no indication of approaching critical levels of reserve depletion (Cunjak and Power 1986). Similarly, a population of bluegills (Lepomis macrochirus) actually came out of winter in better condition than the state they entered, due to previously unreported high feeding rates (Cargnelli and Gross 1997). While winter may be the most important period for mortality of brook trout, it is apparent that winter feeding can lead to coverage of metabolic costs and that generally lipid and protein stores are sufficient to survive to the winter.

\section{Harvest Effects}

If winter survival is not a critical problem in brook trout populations, and large movements are minimal (as in Logan 2003), then large fish should be present in significant numbers in headwater streams in the spring. However, preliminary data suggest otherwise. Sampling in the Monongahela National Forest, West Virginia (2002- 
2003) found reductions in numbers of large fish following winter in small streams. Surveys of six different streams produced few fish greater than $150 \mathrm{~mm}$ in length $(\mathrm{N}=$ 25), and even fewer more than $200 \mathrm{~mm}(\mathrm{~N}=3)$ (Unpublished data). Although it is possible that these fish emigrated from the system, Logan (2003) reported that brook trout generally moved less than $500 \mathrm{~m}$ in spring (March - May). These streams were sampled in early and late May suggesting that some mechanism is depleting the populations over winter or before sampling occurs. Since several studies have shown that trout have ample energy stores to survive this critical period, another stressor is likely contributing to the mortality of these populations.

One possible explanation is previously unknown angler impact on brook trout populations in headwater streams. In general, anglers will often target the larger fish in a system. For Central Appalachian brook trout populations, these are the age-2 to age-4 fish. Preferential harvesting of older trout could have deleterious effects on the populations of this species.

The most prominent effect of angler harvest on fish populations is the change in the age and size structure of the population. Anderson and Nehring (1984) discovered that anglers can alter species composition, biomass, age, and size structure of fish populations depending on the level of exploitation. Harvesting of larger, older fish can lead to a shift in population structure to younger, smaller fish (Hunt 1981). Heavily exploited populations of trout result in a population dominated by faster-growing fish (Healey 1975, Brauhn and Kincaid 1982). A population dominated by these fish may have several effects. Faster growing fish will reach the legal size limit quicker, and therefore be harvested at a younger age. Trout populations dominated by young fish can 
exhibit faster growth (Brana et al. 1992), and less diversity of growth rates than unexploited populations (Healey 1975). Not only can harvest decrease the number of older individuals, but in the long run, the population's age structure may become much less diverse. In addition, it has been reported that the important factor in having balanced fish populations is having sufficient numbers of larger fish (Gigliotti and Taylor 1990). If these large fish are selectively harvested, and the populations do not have enough time to recover, then there will be fewer trout for anglers to catch in the future.

Unfortunately, little research has been done on the effects of anglers on brook trout in headwater streams. This is surprising considering the amount of harvest that occurs on larger size streams. On a Wisconsin stream, angler harvest approached or exceeded a level of overexploitation for trout (Hunt 1984) resulting in 34\% fewer trout in the stream. Similarly, exploitation rates of brown trout in four streams in Wisconsin ranged from 11-24\% (Hunt 1981). High harvest rates can potentially reduce the spawning stock density enough to depress natural recruitment, and in extreme cases decrease the ability of the population to maintain sufficient numbers (Hunt 1981). If anglers can have a major impact on fisheries populations, it is necessary to understand the role and magnitude of the harvest on game species like brook trout in order to truly grasp the fluctuations in a population.

Several factors can determine the survival of brook trout over a yearly cycle: The relative growth of energy reserves (lipid and proteins) in spring, the ability to transfer these resources to gametes during lean summer months, and the necessity of having sufficient stores to survive the winter. Although winter is a time of increased mortality in brook trout populations, previous studies have shown that most fish have enough lipids 
and proteins stored to survive this critical period. Preliminary data have shown that large brook trout are absent from spring surveys in West Virginia even though they should have enough energy to survive the winter. This data points to a possible outside stressor changing the structure of brook trout populations in West Virginia headwater streams. This stressor may be due to angler harvest early in the spring months. Studies indicate that anglers can have several significant detrimental effects on a brook trout population. For these reasons, the objectives of this study on West Virginia brook trout populations in headwater streams are two-fold. First, we will examine relative changes in body composition of brook trout as they fluctuate throughout the year, and identify critical periods of survival to determine if brook trout reach critical levels of resource depletion over winter; second, we will evaluate whether angler harvest affects brook trout populations in spring in headwater streams. 


\section{Literature Cited}

Anderson, R. M. and R. B. Nehring. 1984. Effects of a catch-and-release regulation on a wild trout population in Colorado and its acceptance by anglers. North American Journal of Fisheries Management 4: 257-265.

Berg, O. K. and G. Bremset. 1998. Seasonal changes in the body composition of young riverine Atlantic salmon and brown trout. Journal of Fish Biology 52: 1272-1288.

Brana, F., A. G. Nicieza, and M. M. Toledo. 1992. Effects of angling on population structure of brown trout, Salmo trutta L., in mountain streams of Northern Spain. Hydrobiologia 237: 61-66.

Brauhn, J. L. and H. Kincaid. 1982. Survival, growth, and catchability of rainbow trout of four strains. North American Journal of Fisheries Management 2: 1-10.

Bridcut, E. E. and P. S. Giller. 1995. Diet variability and foraging strategies in brown trout (Salmo trutta): an analysis from subpopulations to individuals. Canadian Journal of Fisheries and Aquatic Sciences 52: 2543-2552.

Cargnelli, L. M. and M. R. Gross. 1997. Fish energetics: larger individuals emerge from winter in better condition. Transactions of the American Fisheries Society 126: 153-156.

Cunjak, R. A. and G. Power. 1987. The feeding and energetics of stream-resident trout in winter. Journal of Fish Biology 31: 493-511.

Cunjak, R. A. and G. Power. 1986. Seasonal changes in the physiology of brook trout, Salvelinus fontinalis (Mitchill), in a sub-Arctic river system. Journal of Fish Biology 29: 279-288.

Cunjak, R. A., R. A. Curry, and G. Power. 1987. Seasonal energy budget of brook trout in streams: implications of a possible deficit in early winter. Transactions of the American Fisheries Society 116: 817-828.

Elliot, J. M. 1967. The food of trout (Salmo trutta) in a Dartmoor stream. Journal of Applied Ecology 4: 59-71.

Elliott, J. M. 1976. The energetics of feeding, metabolism, and growth of brown trout (Salmo trutta L.) in relation to body weight, water temperature and ration size. Journal of Animal Ecology 45: 923-948.

Elliott, J. M. and M. A. Hurley. 1997. A functional model for maximum growth of Atlantic salmon parr, Salmo salar, from two populations in northwest England. Functional Ecology 11: 592-603. 
Elliott, J. M., M. A. Hurley, and R. J. Fryer. 1995. A new, improved growth model for brown trout, Salmo trutta. Functional Ecology 9: 290-298.

Gigliotti, L. M. and W. W. Taylor. 1990. The effect of illegal harvest on recreational fisheries. North American Journal of Fisheries Management 10: 106-110.

Healey, M. C. 1975. Dynamics of exploited whitefish populations and their management with special reference to the Northwest Territories. J. Fish Res. Board Can. 32: 427-446.

Hunt, R. L. 1974. Annual production by brook trout in Lawrence Creek during eleven successive years. Wisconsin Department of Natural Resources Technical Bulletin 82.

Hunt, R. L. 1981. Population dynamics of wild brown trout and associated sport fisheries in four central Wisconsin streams. Wisconsin Department of Natural Resources Technical Bulletin 121: 1-22.

Hunt, R. L. 1984. Results and trout management implications of a 9-month creel census on Timber Coulee Creek in 1984. Wisconsin Department of Natural Resources Technical Bulletin 135: 1-23.

Hutchings, J. A., A. Pickle, C. R. McGregor-Shaw, and L. Poird. 1999. Influence of sex, body size, and reproduction on overwinter lipid depletion in brook trout. Journal of Fish Biology 55: 1020-1028.

Jenkins, R. E. and N. M. Burkhead. 1993. Freshwater fishes of Virginia. American Fisheries Society. Bethesda, Md.

Karas, N. 2002. Brook trout: A thorough look at North America's great native trout - its history, biology, and angling possibilities. 2nd ed. The Lyons Press. Guilford, Conn.

Keast, A. 1968. Feeding of some Great Lakes fishes at low temperatures. Journal of the Fisheries Research Board of Canada. 25: 1199-1218.

Logan, M. N. 2003. Brook trout (Salvelinus fontinalis) movement and habitat use in a headwater stream of the Central Appalachian Mountains of West Virginia. Master's Thesis. 1-63.

Love, R. M. 1970. The chemical biology of fishes. Academic Press. London.

Needham, P. R., J. W. Moffett, and D. W. Slater. 1945. Fluctuations in wild brown trout populations in Convict Creek, California. Journal of Wildlife Management 9: 925.

Sagar, P. M. and G. J. Glova. 1988. Diel feeding periodicity , daily ration and prey selection of a riverine population of juvenile chinook salmon, Oncorhynchus 
tshawytscha (Walbaum). Journal of Fish Biology 33: 643-653.

Shearer, K. D., T. Asgard, G. Andorsdottir, and G. H. Aas. 1994. Whole body elemental and proximate composition of Atlantic salmon (Salmo salar) during the life cycle. Journal of Fish Biology 44: 785-797.

Sweka, J. A., M. K. Cox, and K. J. Hartman. 2004. Gastric evacuation rates of brook trout. Transactions of the American Fisheries Society 133: 204-210.

Whitworth, W. E. and R. J. Strange. 1983. Growth and production of sympatric brook trout and rainbow trout in an Appalachian stream. Transactions of the American Fisheries Society 112: 469-475. 


\title{
Chapter 2. Investigation of possible seasonal population bottlenecks in brook trout (Salvelinus fontinalis) in Central Appalachian headwater streams.
}

\author{
Abstract \\ Brook trout (Salvelinus fontinalis) in the Appalachian Mountains often inhabit \\ low production streams that likely limit growth. Identifying periods of growth and \\ mortality are important in managing these stream salmonids. Therefore the objective of \\ this study was to examine seasonal changes in body composition of age- 1 and older \\ brook trout to identify critical periods of growth or depletion that may lead to mortality, \\ and to determine if brook trout in headwater streams reach critical levels of resource \\ depletion over winter. Six streams in the Central Appalachian Mountains in West \\ Virginia containing naturally reproducing brook trout were sampled from June 2003 to \\ March 2004 to assess changes in brook trout physiology. Dry, protein, and fat weights \\ were highest in early summer (June) and decreased through the November/ December \\ sampling period. To better understand how body composition of trout changes over \\ winter we starved 40 brook trout in experimental tanks simulating winter conditions (low \\ temperatures, similar photoperiod) and estimated body composition using bioelectrical \\ impedance analysis. Weights and percent weights of dry matter, protein, and fat were \\ higher at the beginning (Week 1) and end (Week 9) of the experiment compared to wild \\ trout entering (November/ December) and exiting winter (February/ March). The low \\ rates of fat and protein loss during simulated winter conditions suggest that brook trout \\ likely do not starve during the year. Therefore, managers must other stressors when \\ identifying population bottlenecks in these fishes in headwater streams.
}




\section{Introduction}

A limited food base has severely limited growth rates of brook trout (Salvelinus fontinalis) in the Appalachian Mountains (Cada et al. 1987). In fact, stream salmonids often inhabit environments possessing limited food and resources (Keeley and Grant 1997), and West Virginia streams are no exception. The daily ration of brook trout in this region may be below maintenance ration after spawning (Sweka and Hartman 2001a). Post-spawning is an energetically limiting time for trout that may lead to mortality because of low food availability and low growth potential due to low temperatures. Lipid stores decrease quickly (Berg and Bremset 1998), and body condition is at its lowest point in trout after spawning in the fall (Cunjak and Power 1987).

Winter is considered the critical period in life for stream salmonids (Whitworth and Strange 1983). Rapidly falling temperatures, decreased food abundance, and possible ice-over are all hazards brook trout must face in Central Appalachian headwater streams. To survive the harsh winter, fish must rely on stored energy sources when food is scarce (Keast 1968). This can be especially critical for mature trout that have spawned the previous fall. Already low in energy, few opportunities exist to recover energy lost to spawning. Food availability to brook trout was shown to be very low during winter in West Virginia headwater streams (Sweka and Hartman 2001a) and this suggests winter may be a season of energy depletion that could lead to high mortality for brook trout in this region. Survival in winter for brook trout depends on the amount of energy stores present during these lean months.

Often, lipid stores are used quickly in early winter (Berg et al. 1998) as water temperatures drop sharply. In Atlantic salmon (Salmo salar), both lipid and protein 
levels decreased over the winter months (Berg and Bremset 1998, Shearer et al. 1994). Similar decreases have been documented in sub-arctic brook trout populations (Cunjak and Power 1986). Although it is well-known that winter is a major period of mortality for trout (Whitworth and Strange 1983), it is unknown what critical levels of fat and protein put brook trout at greater risk of death.

Bioelectrical Impedance Analysis (BIA) allows us to monitor changes in fish proximate body composition without killing the fish. It is a non-invasive way of studying relative proportions of lipid, dry weight, protein, water, and ash levels as a fish's body changes due to environmental influences (Cox 2004). We can use it to examine changes in fish body composition throughout the year, and thus identify possible population bottlenecks. Therefore the objective of this study was to examine seasonal changes in body composition of age-1 and older brook trout to identify critical periods of energy depletion that may lead to mortality.

\section{Study Area}

Six West Virginia streams were used in this study. Elklick Run is located in the Fernow Experimental Forest, and Red Run is a special regulations, catch-and-release only stream. Both are part of the Cheat River drainage system and located in Tucker County. Whites Run in Pendleton County, is part of the South Branch of the Potomac River Watershed. Poca Run and Clubhouse Run are part of the Greenbrier River watershed, and both are found in Pocahontas County. Rocky Run is within the MeadWestvaco Wildlife and Ecosystem Research Forest in Randolph County, and flows into the Middle Fork River. All streams except Rocky Run are located in the 
Monongahela National Forest. The forest is located within the Appalachian Plateau and is characterized by mountainous land forms.

The six sites are headwater streams $\left(1^{\text {st }}\right.$ and $2^{\text {nd }}$ order $)$, with each stream supporting naturally-reproducing brook trout populations, and are characterized by riparian vegetation made up of mixed-deciduous hardwoods. Unique features include a reservoir at the top of Elklick Run that in previous years provided drinking water for local residents, and Red and Rocky Runs are treated every year in their headwaters with limestone sand by West Virginia Division of Natural Resources to buffer against acidic waters. Mean hourly temperatures for 2003 ranged from $9.2-11.1{ }^{\circ} \mathrm{C}$ (Figure 1) in these streams (Note: Elklick Run and Rocky Run not included due to loss of temperature loggers). Low flow can become a problem in drought years as in 2002, when several neighboring streams stopped flowing altogether.

\section{Methods}

\section{Fish Collection}

The six streams were sampled four times in 2003-2004 to evaluate changes in brook trout body composition as affected by season. The spring/ summer sampling period occurred on 13 - 16 June, the pre-spawn period on 26 September - 10 October, post-spawn on 21 November - 3 December, and the post-winter period on 25 February 10 March. To sample the brook trout populations in each stream, three $100 \mathrm{~m}$ stream reaches were chosen. Each reach was representative of the habitat areas of each stream. Three-pass removal using a DC-pulse backpack electrofisher was used to obtain trout for population estimates, and body composition estimates. Based on calculated sample sizes, the target number of trout per stream for proximate composition analyses was seventy 
individuals because this allowed us a minimum detectable difference of $0.25 \mathrm{~g}$ when comparing mean body composition weights between streams. If 70 brook trout were not obtained in the 3-100 m study sections, additional sampling from outside of the reach was conducted in an effort to achieve the target sample size for body composition analyses. Block nets were used at the end of each section to limit emigration or immigration during sampling.

Brook trout population estimates were calculated using Program 2CAPTURE (White et al.1982). Separate population estimates were also calculated for stock-sized trout (> $130 \mathrm{~mm}$ total length according to Willis et al. 1993) for each section of each stream. Brook trout population estimates were also used to calculate percent population declines for each stream over winter.

Upon completion of the electrofishing pass, brook trout were immediately anesthetized with $120 \mathrm{mg}$ clove oil per liter of water (Anderson et al. 1997) and the total length (TL in millimeters) and wet weight (grams) of each fish were measured. Subsequently, trout were measured for proximate body composition using BIA (described in next section), and placed into a live well to monitor condition before being released back into the stream. Only brook trout between $110 \mathrm{~mm}$ and $285 \mathrm{~mm}$ TL were used for BIA composition estimates because they represent the range of values used in the Cox (2004) BIA models for brook trout.

\section{Experimental stream setup}

To examine how winter conditions affect brook trout body composition we simulated winter conditions in a West Virginia headwater stream in a laboratory setting. Two Living Stream units (Frigid Units, Inc.) each with a volume of $0.41 \mathrm{~m}^{3}$ were used to 
house the brook trout in this experiment. Brook trout were obtained from Bowden Fish Hatchery, West Virginia. Each tank contained 20 brook trout with a size range of 160 $322 \mathrm{~mm}$ TL. To simulate winter conditions, water in each tank was kept at $1-2^{\circ} \mathrm{C}$ for nine weeks (the number of weeks temperatures were below $2^{\circ} \mathrm{C}$ in study streams during the 2003-2004 winter period, see Figure 1). Photoperiod remained constant for both tanks with 8 hours of daylight and 16 hours of darkness.

Bioelectrical Impedance Analysis was used to estimate proximate body composition of the experimental trout on a weekly basis. Fish were anesthetized and processed as in field collections, recording total lengths, wet weights and BIA measurements on a weekly basis.

\section{Bioelectrical Impedance Analysis}

Bioelectrical Impedance Analysis was used to obtain proximate body composition of all brook trout in our study. BIA is a non-lethal way of approximating several body constituents including, dry weight, wet weight, total protein, total fat, fat free mass and total ash content (Cox 2004). The methods for BIA can be found in Cox (2004), therefore I give only a brief explanation of the methodology here.

BIA estimates proximate body composition by sending a weak electrical current (low voltage, high frequency) through the fish's body while it is sedated. The current passes through the extracellular fluids, and at high frequencies the cell walls become receptive to the current. As a result, the resistance and reactance numbers are sensitive to changes in volume of cellular and extra-cellular material (Cox 2004). The estimations are calculated by measuring the impedance (resistance and reactance) of the current as it passes through the fish (Cox 2004). The impedance was measured using a tetrapolar 
bioelectrical impedance analyzer (RJL Systems, Detroit, MI). The instrument used on each fish consists of two sets of two needles attached to calipers, which are connected to the analyzer. Each set of needles contain a signal electrode and detector electrode located $1 \mathrm{~cm}$ apart from each other. The needles are inserted $1 \mathrm{~mm}$ into the fish with the first set in the anteriad dorsad region, and the second set in the caudal peduncle area (Cox 2004). We then measured the distance between the two detecting electrodes for each fish, and a current was sent through two signal electrodes, while the two detecting electrodes measured the voltage drop. We used resistance and reactance to calculate values from electrical property equations that included resistance in series and in parallel, reactance in series and in parallel, combined resistance and reactance in series and in parallel, and capacitance (Cox 2004). Obtained values were subsequently used as independent variables in a regression model (Cox 2004). The trout used in the Cox (2004) model were between $110 \mathrm{~mm}$ and $285 \mathrm{~mm}$ TL, and $10.5 \mathrm{~g}$ to $242 \mathrm{~g}$ total wet weight, therefore only fish found to be in this range were analyzed in our study. Percent body compositions were calculated using the general relationship:

1) $\% \mathrm{PAR}=(\mathrm{PAR} / \mathrm{WGT}) * 100$, where PAR is the percent body composition component in question (total body water, fat, ash, etc.), PAR is the same composition component predicted by BIA, and WGT is total weight predicted by BIA.

In addition, percent protein and fat weights were divided by dry weight to exclude any confounding effects of changes in water mass. Total energy was determined as the sum of the calories in the tissues of the trout, where protein was assigned a value of 24 
$\mathrm{kJ} / \mathrm{g}$ and fat was assigned $39 \mathrm{~kJ} / \mathrm{g}$ (Jobling 1995). Bioelectrical impedance analysis can result in bleeding and bruising of the skin, but deaths are rare (Cox 2004).

\section{Statistical Analysis}

Differences in mean percents of dry, protein, fat and ash weights between streams and between seasons were analyzed using SAS (Version 8). Since large trout allocate these body constituents proportionately more than smaller ones, we ran separate analyses for large brook trout. We determined that percent body composition (dry, protein, fat, and ash weights) has a significant relationship with TL of brook trout for all seasons and streams combined (Figure 2, $\mathrm{P}<0.0001$ for each). Therefore, we used analysis of covariance (ANCOVA) using TL as the covariate, to analyze the data sets. Specifically, a two-factor completely random design ANCOVA was used to identify these differences in all trout that fit the model, and separately in trout greater than $130 \mathrm{~mm}$ TL to understand how the body composition of larger trout vary across time. In addition, ANCOVA was used to locate differences between mean percents of proximate body composition between males and females during the spawning months (SeptemberNovember). A split-plot ANCOVA was used to identify differences between weekly means (fat, protein, dry weight, energy) in the winter simulation experiment, while a completely random design ANCOVA was employed to look for differences in means between wild and laboratory brook trout. SAS was also used to generate standard deviations and $95 \%$ confidence intervals for all analyses described. Alpha was set at the 0.05 level.

Percent data were not normally distributed, and were transformed as follows: dry weight and protein were transformed using arcsin, fat weight using a square root 
transformation, and a $\log _{10}$ transformation for ash weight of the fish. Different transformations were used to ensure each data set was normally distributed, and that assumptions for ANCOVA were met. Subsequent data sets (spawning, stock size trout) were analyzed using the same transformations to approximate normality.

\section{Results}

Populations of stock-size brook trout for all streams combined were highest in the pre-spawn sampling period, and lowest following winter (Figure 3). The explanations for these declines in large trout numbers are the subject of our field and laboratory composition studies.

\section{Seasonal body composition estimates}

BIA predicted total weight well for combined data from all streams over the four sampling periods (Figure 4, $\mathrm{R}^{2}=0.99$ ), which gave us confidence in estimating other body composition constituents. Mean percent dry weights ranged from $17.1 \%$ to $24.3 \%$ of the total weight of the trout (all sizes) over the four sampling periods. They were highest in June (summer) for all streams except Red Run, where the highest percent dry weights were recorded in September/ October (pre-spawning) (Table 1). The lowest values varied by stream, but were typically lowest in November/ December (postspawning) or February/ March (early spring). Percent protein weight followed a similar trend with the highest values coming in summer (except Red Run), and ranging from $14.5 \%$ to $16.8 \%$. Percent fat weights were consistently higher at Elklick Run than the other streams, but were still typically low across all seasons. Fat estimates ranged from $1.03 \%$ to $5.10 \%$. Only Poca Run did not show a significant change for any body composition estimate between the pre- and post-spawning periods. 
Mean percent dry weights for streams combined decreased from June to November/ December, and increased over winter (Figure 5). This same trend was seen in mean percent protein and fat for all streams combined. Proximate body composition results for individual streams were similar to the general trend with some exceptions (Figure 6). Percent dry weights declined at all streams during the spawning months, and most (excluding Poca and Rocky Runs) increased over winter likely resulting in more individual mass and energy in the population. Percent protein and percent fat weights followed the same trend with June being the highest month in all streams (except Elklick Run). Rocky Run was the only stream with significant decreases in percent dry and protein weights $(\mathrm{P}=0.04$ and $\mathrm{P}=0.04$, respectively) between pre- and post-winter sampling periods, indicating a possible decrease in energy over winter.

Percent protein and ash of the dry weight increased over the year for all streams combined, but decreased over winter (Figure 7). Percent fat of the dry weight followed a completely opposite trend, decreasing from June to November and increasing over winter. Further, Whites Run and Red Run both significantly declined in percent protein ( $\mathrm{P}=0.04$ and $\mathrm{P}<0.001$, respectively) and percent ash of the dry weight over winter $(\mathrm{P}=$ 0.03 and $\mathrm{P}<0.001$, respectively).

A total of 405 adult brook trout were analyzed for proximate body composition in the pre- and post-spawning months (Table 2). Percent dry, protein, and fat weights were highest in males and females prior to spawning. Notably, males were significantly higher than females in dry, protein, and fat weights in September $(\mathrm{P}<0.05)$. Females were significantly higher in all body composition variables measured during the pre-spawning 
months $(\mathrm{P}<0.05)$ compared to females after spawning. The same trend was seen when comparing male brook trout between pre- and post-spawning months $(\mathrm{P}<0.05)$.

\section{Simulated winter experiment}

Estimates of proximate body composition of brook trout changed little during the simulated winter experiment. Mean dry weight, protein, and fat content were all higher in experimental brook trout for Weeks 1 and 9 than in the pre- and post-winter sampling periods of the wild trout (Figure 8). Protein and fat weights did not change by more than 0.5 grams over the nine weeks of the experiment (Figure 9). Protein, and fat content in Week 1 were not significantly different than in Week $9(\mathrm{P}=0.30, \mathrm{P}=0.17$, respectively).

Brook trout from all streams were above the critical mean fat level $(0.2 \mathrm{~g}$ determined by Simpkins et al. (2003a) using juvenile rainbow trout (120-142 mm TL), Oncorhynchus mykiss in pre- (November/ December) and post-winter (February/ March) sampling periods (Figure 10), although mean fat content of trout in all streams appeared to decrease over winter except those from Elklick Run and Red Run. Total energy stores of stock-size trout decreased in all streams between pre- and post-winter sampling periods except for Rocky Run (Figure 11). Only at Elklick Run and Red Run did total energy of brook trout decrease significantly over winter $(\mathrm{P}<0.05$ and $\mathrm{P}<0.05$, respectively).

\section{Discussion}

Stock-size brook trout from all streams decreased in number over the winter season. Proximate body analyses indicated periods of rapid body growth (spring) and depletion of reserves (fall, winter) in brook trout in headwater streams. Brook trout under 
simulated winter conditions changed little in dry, protein, and fat weights. Similarly, brook trout in some streams increased in actual fat and \% fat weights over winter. Therefore, it is reasonable to conclude that age- 1 and older brook trout did not starve in these six headwater streams in the winter of 2003-2004.

Dry weight, proteins, and lipids were generally highest in the June sampling period in all streams. These elevated body composition estimates in June are likely the result of rapid growth exhibited by these fish in spring. This growth is likely a function of increased prey availability and increased water temperatures (Elliott et al. 1995) typical of this time of year. Levels of body lipids were similar to those seen in brook trout in sub-arctic populations (Cunjak and Power 1986) in early summer (June). A similar pattern was seen in Atlantic salmon (Salmo salar) with the rapid increase in fat being attributed to rapidly increasing water temperatures (Berg and Bremset 1998). Spring was likely the most important period of growth for brook trout because food was more available, and water temperatures were elevated allowing increased gastric evacuation rates. Protein masses also increased in trout populations in our study streams possibly because they were replacing depleted stores used over winter, as was observed in northern brook trout populations (Cunjak and Power 1986).

A second important time in the life of stream salmonids is late summer when there is high energy demand for gamete production. Spawning in fish can lead to periods of rapid tissue building, high energy demands, and transfer of somatic material to the gonads (Shearer et al. 1994). High levels of protein and lipid reserves at this time of year have been recorded in other brook trout populations (Cunjak and Power 1986). As a result, we might have expected to see another increase in protein and lipid reserves in the 
sexually mature brook trout similar to other populations, but levels decreased from June. It is likely that increased water temperatures $\left(15^{\circ} \mathrm{C}\right.$ mean temperature in July and August) and decreased flows in these headwater streams led to an energetically stressful time for trout, subsequently decreasing lipid reserves. In addition, possible food limitation may have led to decreased energy stores. Brook trout populations have been shown to decrease significantly during a drought at this time of year in similar sized streams (Hartman and Hakala 2004).

Mature female trout find themselves at more of a disadvantage after spawning because they have allocated more energy to reproduction. In our study, females' protein and fat content decreased $5 \%$ and $37 \%$, respectively, while males only decreased $1 \%$ in protein, and $9 \%$ in fat weight. This discrepancy between the sexes is consistent with other salmonids (Berg et al. 1998, Jorgensen et al. 1997). Therefore, female brook trout may have a higher probability of mortality over winter, which could lead to a change in population structure. It must be considered that when sampling commenced in late September, some trout may have already begun spawning. This may have led to lower levels of fat in spent trout.

Since levels of protein and lipids were lowest in trout from all streams in November and December, it appears that winter may be a population bottleneck for brook trout during the year. Spawning adults already depleted of energy stores now must acclimate to rapidly decreasing water temperatures. Berg and Bremset (1998) found that lipids decrease fastest in early winter, and body condition is also at its lowest point (Cunjak and Power 1987). Other studies have shown similar lipid deficiencies (Cunjak 
and Power 1986, Shearer et al. 1994), but few are clear on how critical this deficit is to survival.

Proximate body composition of trout exiting winter indicated that individuals likely did not reach critical levels of resource depletion even though winter is thought of as a period of high mortality in brook trout (Whitworth and Strange 1983). In addition, it appears that brook trout in the headwater streams in this study did not starve over the winter months. It is important to note that protein stores did not decrease significantly (except Rocky Run) from early to late winter, and these are not typically used until fat levels are severely depleted (Love 1970). Populations of large trout at Rocky Run exhibited significant decreases in percent dry and protein weights. Trout at Rocky Run also displayed the largest decline in population (39.6\%) over winter. Similarly, fishes at Whites Run and Red Run decreased in percent protein of dry weight over winter, but only Whites Run showed a large population decline (27.8\%). Brook trout in these streams may have mobilized proteins for periods of active swimming (higher flows), but this cannot be confirmed because flow data was not measured at the streams in this study. These data show that there is no clear relationship between changes in protein levels and population decline, therefore survival may be more closely linked to relative amounts of lipids in brook trout during critical times of the year. However, other studies have not been able to confirm the link between lipids and survival (Berg et al. 1998, Berg and Bremset 1998, Cunjak and Power 1986, Shearer et al. 1994).

In addition, there was no estimate of winter mortality of brook trout, and if individual trout died from exhaustion of energy reserves they would not be included in the analyses. This could lead to inflated estimates of body composition estimates, but as 
in Cunjak and Power (1986) surviving trout did not show any signs of approaching critical levels. Unfortunately, sampling trout mid-winter went beyond the scope of this study. If we had sampled at this time we may have found greater numbers of trout with lower fat and protein levels.

To test these findings we studied trout in a simulated winter experiment. The lack of any significant change in fat and protein in the experimental trout is likely a result of the water temperature being kept between 1 and $2^{\circ} \mathrm{C}$. Trout held at lower temperatures tend to exhibit slower metabolisms that may allow them to survive longer periods without food. Similarly, other fish have shown minimal change in lipid levels over a similar time period under simulated winter conditions (Sogard and Olla 2000). The trout in our experiment were relatively sedentary due to the lack of any substantial flow in the experimental tanks. Sedentary juvenile rainbow trout at $4^{\circ} \mathrm{C}$ did not show any mortality and little lipid loss over a 9 week period (Simpkins et al. 2003a). Lipid loss was also minimal in starved trout over a 45-day period (Denton and Yousef 1976). Therefore, it may be expected to observe little depletion in fat content under laboratory winter conditions, as we saw in brook trout in our study.

Although we may expect brook trout in headwater streams to be more active than our laboratory fish, it is still likely that these fish will seek out velocity refuges during the winter months. Therefore, if trout in the wild are using pool habitats in winter, they are more likely to conserve energy and lipid stores. Thus, we may conclude that neither population of trout (experimental or wild) approached critical levels of resource depletion if we consider lipids to be a good indicator of survival (Simpkins et al. 2003b). Sogard and Olla (2000) found that mortality did not occur in walleye pollock (Theragra 
chalcogramma) until lipid levels dropped below $7 \%$ of the dry weight. In our study, brook trout in natural stream conditions exited winter with lipids close to $13 \%$ of the dry weight, and laboratory fish were even higher. Similarly, juvenile rainbow trout did not show mortality while being fasted until lipid levels decreased to $0.2 \mathrm{~g}$ (Simpkins et al. 2003a), while brook trout in our six study streams exited winter with fat weights ranging from $0.9 \mathrm{~g}$ to $3.7 \mathrm{~g}$.

If trout in natural stream populations are sedentary, then according to the results of our experiment, these trout are unlikely to use up all of their energy reserves. Actively swimming fish burn energy reserves faster than their sedentary counterparts (Hurst and Conover 2001, Simpkins et al. 2003a, Sogard and Olla 2000), and protein stores are often mobilized first in active fish (Love 1970). This is likely why protein in the wild trout populations made up more of the dry weight than in the experimental fish. As mentioned earlier, brook trout in headwater streams may have mobilized proteins for periods of active swimming (high flows, foraging), which may explain significant declines in protein over winter in some of our streams, whereas the sedentary laboratory fish were inactive and likely used more lipids for maintenance metabolism. Proximate body composition estimates were similar in this study to other populations of brook trout analyzed in northern climes (Cunjak and Power 1986), and of other salmonid species (Shearer et al. 1994).

Growth is greatest in the spring and early summer months followed by mobilization of proteins and lipids to the gonads for the fall spawning months. Females find themselves at more of a reserve deficit upon entering winter than males. It is clear that brook trout undergoing 9 weeks of starvation in cold water $\left(1-2^{\circ} \mathrm{C}\right)$ at a relatively 
sedentary position do not use up their reserves or starve to death. If we consider this similar, if not worse, than the conditions in West Virginia headwater streams in winter, then based on lipid and protein levels of trout exiting winter, wild brook trout will not starve over the winter months. Salmonids are adapted to survive extensive periods without food (Toneys and Coble 1980) by slowing metabolism in colder months. Although winter is a critical time period for brook trout, populations of adult brook trout still declined over the winter of 2003-2004.

Our study showed that abundance of age-1 + trout decreased over winter, yet mortality from starvation cannot explain this. Starvation cannot account for these declines in adult brook trout populations because percent fat levels in these trout actually increased over winter. In addition, it did not appear that these wild trout approached critical levels of fat depletion compared to experimental trout populations. Our simulated winter experiments confirmed previous bioenergetic model predictions (Sweka and Hartman 2001b) that suggest brook trout use very little energy in maintenance, particularly at low water temperatures. As a result, it is likely that perceived mortality of adult brook trout in winter is a result of fish emigrating from the system, or due to anglers depleting them in the early winter months.

Therefore, for biologists to properly manage brook trout, these critical periods must be taken into account. Increased angling pressure on trout as they exit winter, even under catch-and-release regulations, could lead to increased stress and subsequently increased mortality on these fishes with already depleted resources, and may explain changes in adult brook trout population densities in headwater streams. Managers should consider energetic and anthropogenic stressors in the regulations used to manage native 
brook trout fisheries. Management techniques should also focus on streamside management activities that may lead to increased instream production or increased production of terrestrial invertebrates that have been shown to be important to brook trout populations in forested headwater streams (Sweka and Hartman 2001a). 


\section{Literature Cited}

Anderson, W. G., R. S. McKinley, and M. Colavecchia. The use of clove oil as an anesthetic for rainbow trout and its effects on swimming performance. North American Journal of Fisheries Management 17, 301-307. 97.

Berg, O. K., E. Thrones, and G. Bremset. 1998. Energetics and survival of virgin and repeat spawning brown trout (Salmo trutta). Canadian Journal of Fisheries and Aquatic Sciences 55: 47-53.

Berg, O. K. and G. Bremset. 1998. Seasonal changes in the body composition of young riverine Atlantic salmon and brown trout. Journal of Fish Biology 52: 1272-1288.

Cada, G. F., Loar, J. M., and Sale, M. J. 1987. Evidence of food limitation of rainbow and brown trout in southern Appalachian soft-water streams. Transactions of the American Fisheries Society 116: 692-702.

Cox, M. K. 2004. Brook trout bioenergetics and the use of Bioelectrical Impedance Analysis for proximate composition. Dissertation.

Cunjak, R. A. and G. Power. 1986. Seasonal changes in the physiology of brook trout, Salvelinus fontinalis (Mitchill), in a sub-Arctic river system. Journal of Fish Biology 29: 279-288.

Cunjak, R. A. and G. Power. 1987. The feeding and energetics of stream-resident trout in winter. Journal of Fish Biology 31: 493-511.

Denton, J. E. and M. K. Yousef. 1976. Body composition and organ weights of rainbow trout, Salmo gairdneri. Journal of Fish Biology 8: 489-499.

Elliott, J. M., M. A. Hurley, and R. J. Fryer. 1995. A new, improved growth model for brown trout, Salmo trutta. Functional Ecology 9: 290-298.

Hurst, T. P. and Conover, D. O. 2001. Activity-related constraints on overwintering young-of-the-year striped bass (Morone saxatilis). Candadian Journal of Zoology. 79: 129-136.

Jobling, M. 1995. Environmental biology of fishes. Chapman and Hall. London.

Jorgensen, E. H., S. J. S. Johansen., and M. Jobling. 1997. Seasonal patterns of growth, lipid deposition and lipid depletion in anadromous Arctic charr. Journal of Fish Biology 51: 312-326.

Keast, A. 1968. Feeding of some Great Lakes fishes at low temperatures. Journal of the Fisheries Research Board of Canada. 25: 1199-1218.

Keeley, E. R. and Grant, J. W. A. 1997. Allometry of diet selectivity in juvenile Atlantic 
Salmon (Salmo salar). Canadian Journal of Fisheries and Aquatic Sciences 54: 1894-1902.

Love, R. M. 1970. The chemical biology of fishes. Academic Press. London.

Shearer, K. D., T. Asgard, G. Andorsdottir, and G. H. Aas. 1994. Whole body elemental and proximate composition of Atlantic salmon (Salmo salar) during the life cycle. Journal of Fish Biology 44: 785-797.

Simpkins, D. G., W. A. Hubert, C. Martinez del Rio, and D. C. Rule. 2003a. Interacting effects of water temperature and swimming activity on body composition and mortality of fasted juvenile rainbow trout. Canadian Journal of Zoology 81: 16411649.

Simpkins, D. G., W. A. Hubert, C. Martinez del Rio, and D. C. Rule. 2003 b. Physiological responses of juvenile rainbow trout to fasting and swimming activity: effects on body composition and condition indices. Transactions of the American Fisheries Society 132: 576-589.

Sogard, S. M. and B. L. Olla. 2000. Endurance of simulated winter conditions by age- 0 walleye pollock: effects of body size, water temperature and energy stores. Journal of Fish Biology 56: 1-21.

Sweka, J. A. and K. J. Hartman. 2001a. Influence of turbidity on brook trout reactive distance and foraging success. Transactions of the American Fisheries Society $130,138-146$.

Sweka, J. A. and K. J. Hartman. 2001b. Effects of turbidity on prey consumption and growth in brook trout and implications for bioenergetics modeling. Canadian Journal of Fisheries and Aquatic Sciences. 58: 386-393.

Toneys, M. L., and D. W. Coble. 1980. Mortality, hematocrit, osmolality, electrolyte regulation, and fat depletion of young-of-the-year freshwater fishes under simulated winter conditions. Canadian Journal of Fisheries and Aquatic Sciences 37: $225-232$.

White, G. C., D. R. Anderson, K. P. Burnham, and D. L. Otis. 1982. Capture-recapture and removal methods for sampling closed populations. Los Alamos National Laboratory LA-8787-NERP. 235 pages.

Whitworth, W. E. and R. J. Strange. 1983. Growth and production of sympatric brook trout and rainbow trout in an Appalachian stream. Transactions of the American Fisheries Society 112: 469-475.

Willis, D. W., B. R. Murphy, and C. S. Guy. 1993. Stock density indices: development, use, and limitations. Pages 447-481 in Fisheries Techniques. American Fisheries Society, Bethesda, Maryland. 
Table 1. Seasonal data for selected lateral proximate body composition variables of brook trout using Bioelectrical Impedance Analysis for the six study streams. Results of statistical testing between seasons at each location are shown as the significance levels between the appropriate variables.

\begin{tabular}{|c|c|c|c|c|c|}
\hline \multicolumn{3}{|c|}{ Sampling } & \multicolumn{3}{|c|}{ Body Composition (Mean \% Total Weight \pm Std. Dev.) } \\
\hline Stream & Period & $\mathrm{N}$ & Dry Weight & Protein & Fat \\
\hline \multirow[t]{4}{*}{ Clubhouse Run } & June & 17 & $\begin{array}{c}21.8 \pm 0.03 \\
*\end{array}$ & $\begin{array}{c}16.0 \pm 0.01 \\
*\end{array}$ & $\begin{array}{c}3.17 \pm 0.02 \\
\quad *\end{array}$ \\
\hline & Sep/Oct & 44 & $17.8 \pm 0.05$ & $14.7 \pm 0.02$ & $1.58 \pm 0.02$ \\
\hline & Nov/Dec & 28 & $\begin{array}{c}\text { n.s } \\
17.1 \pm 0.05 \\
\text { n.s }\end{array}$ & $\begin{array}{c}\text { n.s. } \\
14.5 \pm 0.02 \\
\text { n.s. }\end{array}$ & $\begin{array}{c}\text { n.s. } \\
1.23 \pm 0.02 \\
\text { n.s. }\end{array}$ \\
\hline & Feb/Mar & 28 & $17.7 \pm 0.04$ & $14.7 \pm 0.01$ & $1.03 \pm 0.02$ \\
\hline \multirow[t]{6}{*}{ Poca Run } & June & 20 & $\begin{array}{c}23.1 \pm 0.03 \\
*\end{array}$ & $\begin{array}{c}16.4 \pm 0.01 \\
*\end{array}$ & $\begin{aligned} 4.20 & \pm 0.02 \\
& *\end{aligned}$ \\
\hline & Sep/Oct & 81 & $22.7 \pm 0.04$ & $16.3 \pm 0.01$ & $3.77 \pm 0.02$ \\
\hline & & & n.s. & n.s. & n.s. \\
\hline & Nov/Dec & 44 & $22.0 \pm 0.03$ & $16.1 \pm 0.01$ & $3.26 \pm 0.02$ \\
\hline & & & n.s. & n.s. & n.s. \\
\hline & $\mathrm{Feb} / \mathrm{Mar}$ & 27 & $21.3 \pm 0.03$ & $15.8 \pm 0.01$ & $3.02 \pm 0.02$ \\
\hline \multirow[t]{5}{*}{ Whites Run } & June & 20 & $23.5 \pm 0.04$ & $16.5 \pm 0.01$ & $4.71 \pm 0.02$ \\
\hline & & & n.s. & n.s. & n.s. \\
\hline & Sep/Oct & 47 & $\begin{array}{c}23.4 \pm 0.03 \\
*\end{array}$ & $\begin{array}{c}16.5 \pm 0.01 \\
*\end{array}$ & $\begin{array}{c}4.23 \pm 0.02 \\
*\end{array}$ \\
\hline & Nov/Dec & 39 & $\begin{array}{c}21.9 \pm 0.04 \\
*\end{array}$ & $\begin{array}{c}16.0 \pm 0.01 \\
*\end{array}$ & $\begin{array}{c}3.45 \pm 0.02 \\
\text { n.s. }\end{array}$ \\
\hline & Feb/Mar & 32 & $22.1 \pm 0.04$ & $16.1 \pm 0.01$ & $3.44 \pm 0.02$ \\
\hline \multirow[t]{6}{*}{ Elklick Run } & June & 21 & $24.3 \pm 0.03$ & $16.8 \pm 0.01$ & $5.04 \pm 0.02$ \\
\hline & & & n.s. & n.s. & n.s. \\
\hline & Sep/Oct & 29 & $\begin{aligned} 24.0 & \pm 0.05 \\
& *\end{aligned}$ & $\begin{aligned} 16.7 & \pm 0.01 \\
& *\end{aligned}$ & $\begin{array}{c}5.10 \pm 0.02 \\
*\end{array}$ \\
\hline & Nov/Dec & 35 & $22.2 \pm 0.05$ & $16.0 \pm 0.02$ & $4.06 \pm 0.02$ \\
\hline & & & n.s. & n.s. & n.s. \\
\hline & Feb/Mar & 29 & $22.1 \pm 0.05$ & $16.1 \pm 0.02$ & $3.83 \pm 0.03$ \\
\hline
\end{tabular}

n.s. $=$ not significant; $*=\mathrm{P}<0.05$. 
Table 1 continued. Seasonal data for selected lateral proximate body composition variables of brook trout using Bioelectrical Impedance Analysis for the six study streams. Results of statistical testing between seasons at each location are shown as the significance levels between the appropriate variables.

\begin{tabular}{|c|c|c|c|c|c|}
\hline \multicolumn{3}{|c|}{ Sampling } & \multicolumn{3}{|c|}{ Body Composition (Mean \% Total Weight \pm Std. Dev.) } \\
\hline Stream & Period & $\mathrm{N}$ & Dry Weight & Protein & Fat \\
\hline \multirow[t]{4}{*}{ Red Run } & June & 20 & $\begin{array}{c}23.4 \pm 0.04 \\
\text { n.s. }\end{array}$ & $\begin{array}{c}16.5 \pm 0.01 \\
\text { n.s. }\end{array}$ & $\begin{array}{c}4.42 \pm 0.61 \\
\text { n.s. }\end{array}$ \\
\hline & Sep/Oct & 81 & $\begin{aligned} 24.1 & \pm 0.03 \\
& *\end{aligned}$ & $\begin{array}{c}16.7 \pm 0.01 \\
*\end{array}$ & $\begin{array}{c}4.78 \pm 0.24 \\
*\end{array}$ \\
\hline & Nov/Dec & 57 & $\begin{aligned} 22.3 & \pm 0.03 \\
& *\end{aligned}$ & $\begin{array}{c}16.1 \pm 0.01 \\
*\end{array}$ & $\begin{array}{c}3.58 \pm 0.29 \\
*\end{array}$ \\
\hline & $\mathrm{Feb} / \mathrm{Mar}$ & 47 & $23.2 \pm 0.03$ & $16.4 \pm 0.01$ & $4.21 \pm 0.29$ \\
\hline \multirow[t]{4}{*}{ Rocky Run } & June & 19 & $23.4 \pm 0.04$ & $16.5 \pm 0.01$ & $4.50 \pm 0.58$ \\
\hline & Sep/Oct & 44 & $\begin{array}{c}\text { n.s } \\
22.4 \pm 0.03 \\
\quad *\end{array}$ & $\begin{array}{c}\text { n.s. } \\
16.2 \pm 0.01 \\
\quad *\end{array}$ & $\begin{array}{c}\text { n.s. } \\
3.58 \pm 0.31 \\
*\end{array}$ \\
\hline & Nov/Dec & 39 & $19.2 \pm 0.05$ & $15.2 \pm 0.01$ & $2.08 \pm 0.32$ \\
\hline & $\mathrm{Feb} / \mathrm{Mar}$ & 33 & $\begin{array}{c}\text { n.s } \\
20.0 \pm 0.04\end{array}$ & $\begin{array}{c}\text { n.s. } \\
15.4 \pm 0.01\end{array}$ & $\begin{array}{c}\text { n.s. } \\
2.20 \pm 0.32\end{array}$ \\
\hline
\end{tabular}

n.s. $=$ not significant; $*=\mathrm{P}<0.05$. 
Table 2. Pre- and post-spawning mean lateral proximate body composition data for male (M) and female (F) brook trout in all streams combined for September/ October and November/ December sampling periods. Results of ANCOVA testing between seasons at each location are shown as the significance levels between the appropriate variables.

\begin{tabular}{|c|c|c|c|c|c|}
\hline \multirow{2}{*}{$\begin{array}{c}\text { Sampling } \\
\text { Period }\end{array}$} & \multirow[b]{2}{*}{ Sex } & \multirow[b]{2}{*}{$\mathrm{N}$} & \multicolumn{3}{|c|}{ Body Composition (Mean \% Total Weight \pm Std. Dev.) } \\
\hline & & & Dry Weight & Protein & Fat \\
\hline \multirow[t]{2}{*}{ Sep/Nov } & $\mathrm{F}$ & 103 & $\begin{array}{c}24.2 \pm 0.02 \\
*\end{array}$ & $\begin{array}{c}16.8 \pm 0.01 \\
*\end{array}$ & $\begin{array}{c}4.80 \pm 0.02 \\
*\end{array}$ \\
\hline & M & 118 & $24.3 \pm 0.03$ & $16.8 \pm 0.01$ & $4.92 \pm 0.02$ \\
\hline \multirow[t]{2}{*}{ Nov/Dec } & $\mathrm{F}$ & 86 & $\begin{array}{c}21.8 \pm 0.02 \\
\text { n.s. }\end{array}$ & $\begin{array}{c}16.0 \pm 0.01 \\
\text { n.s. }\end{array}$ & $\begin{array}{c}2.99 \pm 0.02 \\
\text { n.s. }\end{array}$ \\
\hline & M & 98 & $23.6 \pm 0.03$ & $16.6 \pm 0.01$ & $4.46 \pm 0.02$ \\
\hline Sep/Nov & $\mathrm{F}$ & 103 & $\begin{array}{c}24.2 \pm 0.02 \\
*\end{array}$ & $\begin{array}{c}16.8 \pm 0.01 \\
*\end{array}$ & $\begin{array}{c}4.80 \pm 0.02 \\
*\end{array}$ \\
\hline Nov/Dec & $\mathrm{F}$ & 86 & $21.8 \pm 0.02$ & $16.0 \pm 0.01$ & $2.99 \pm 0.02$ \\
\hline Sep/Nov & M & 118 & $\begin{array}{c}24.3 \pm 0.03 \\
*\end{array}$ & $\begin{array}{c}16.8 \pm 0.01 \\
*\end{array}$ & $\begin{array}{c}4.92 \pm 0.02 \\
*\end{array}$ \\
\hline Nov/Dec & $\mathrm{M}$ & 98 & $23.6 \pm 0.03$ & $16.6 \pm 0.01$ & $4.46 \pm 0.02$ \\
\hline
\end{tabular}

n.s. $=$ not significant; $*=\mathrm{P}<0.05$. 
Clubhouse Run

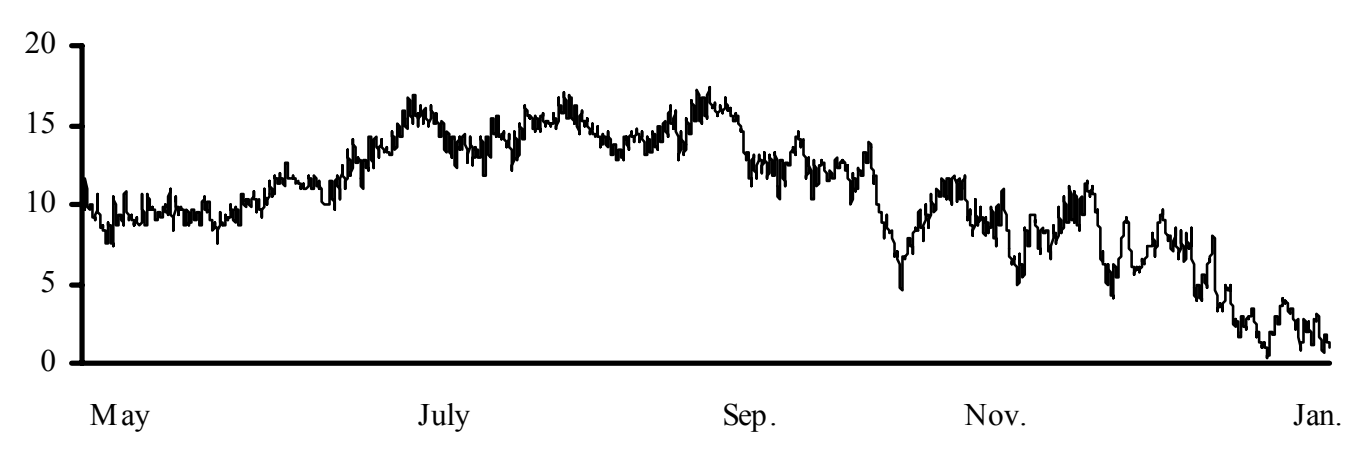

Poca Run
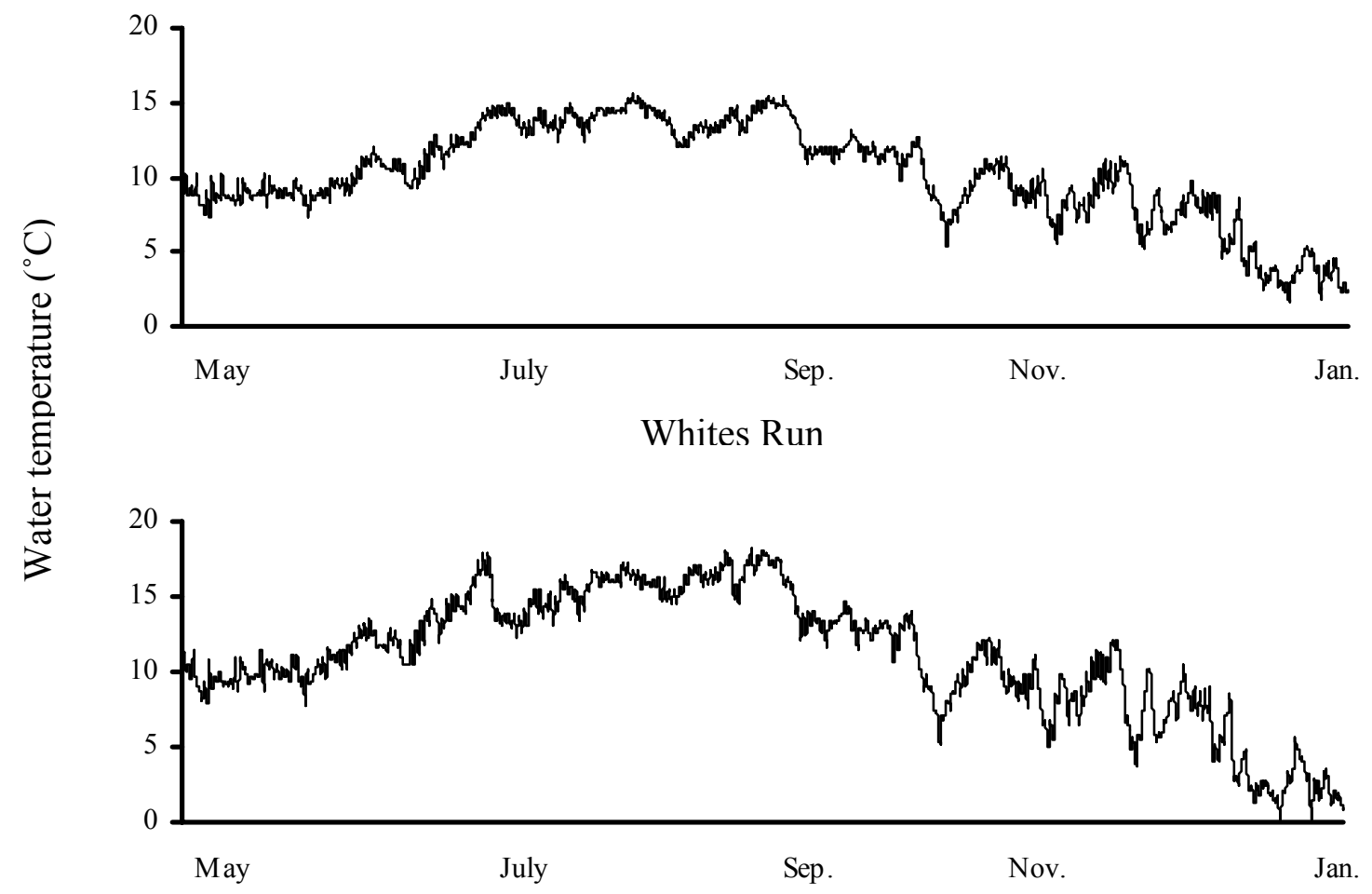

Red Run

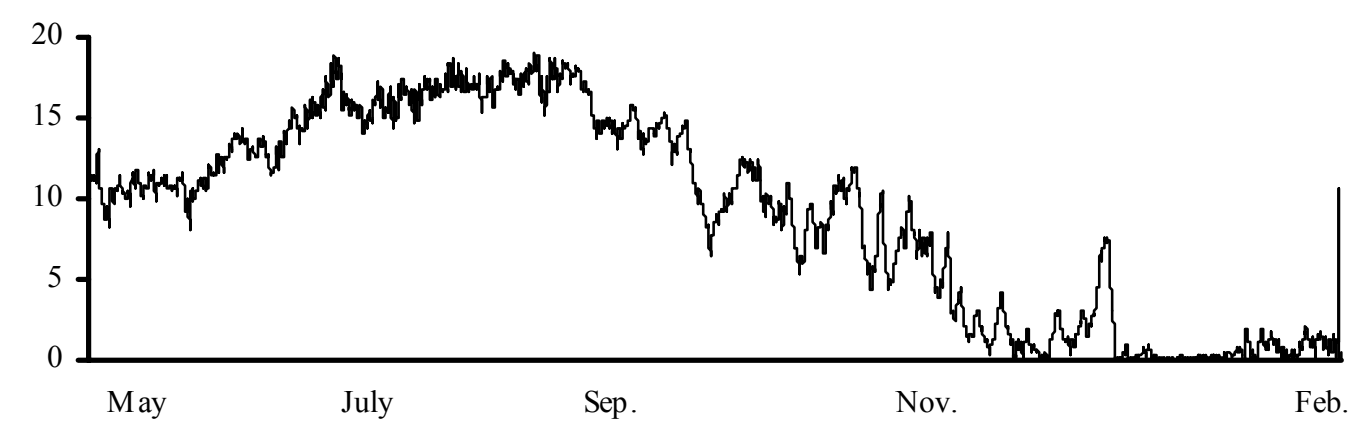

Figure 1. Temperature data for four streams from May 2003 to January and February 2004. Note: Temperature loggers were lost for Rocky and Elklick Runs. 

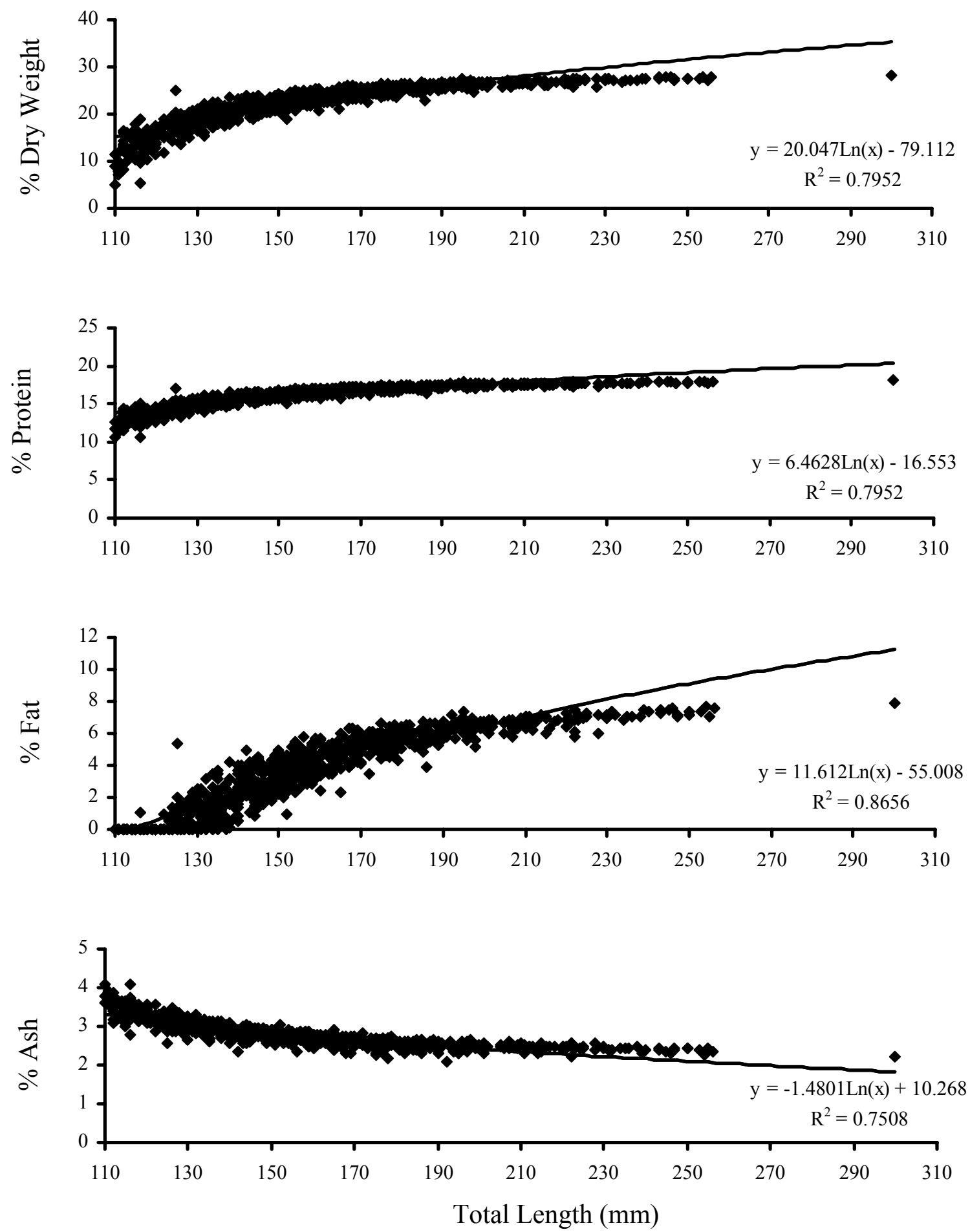

Figure 2. Calculated regression lines of percent body composition of wild brook trout as it relates to total length. Note: All were significant at the alpha $=0.05$ level (all streams and seasons combined). 


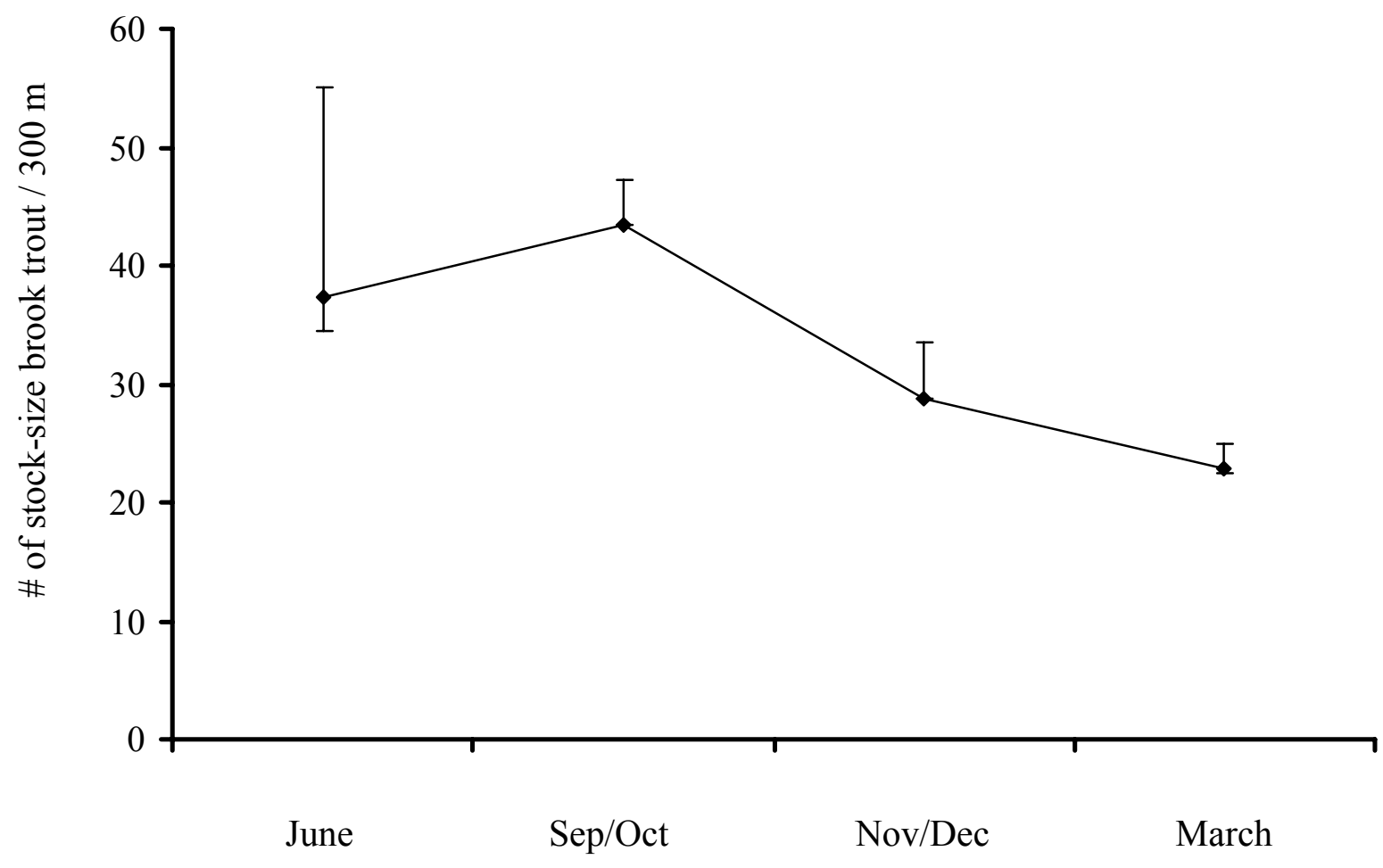

Figure 3. Mean population estimates of stock-size brook trout from all streams combined. Error bars represent $95 \%$ confidence intervals calculated by Program 2Capture. 


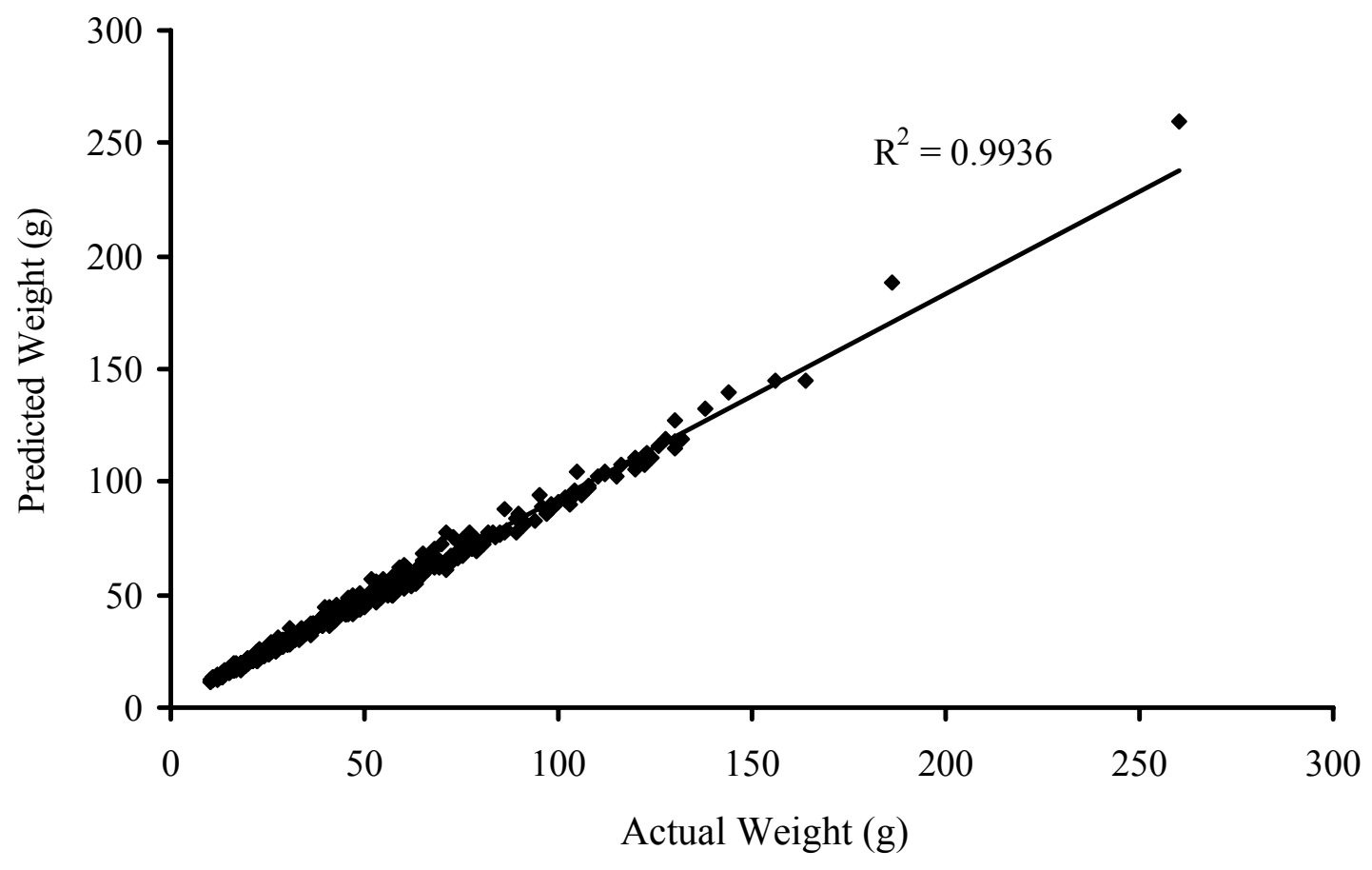

Figure 4. Relationship between actual weight (g) of brook trout and weight predicted by Bioelectrical Impedance Analysis of all fish analyzed in this study. 

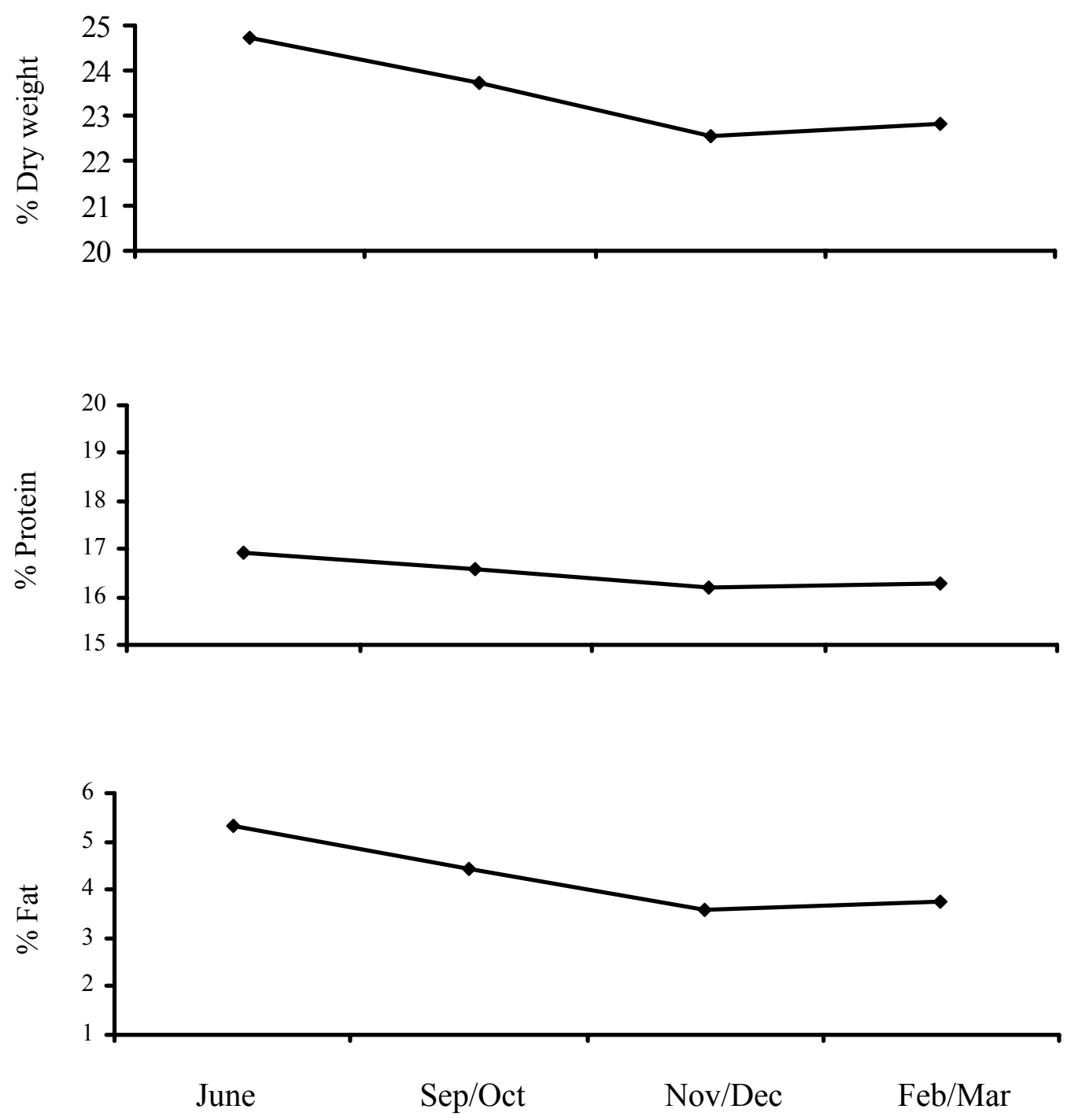

Figure 5. Seasonal mean percent proximate body composition values of brook trout greater than $130 \mathrm{~mm}$ total length for the six study sites combined. Note: June November/ December sampled in 2003, and February/ March in 2004. 

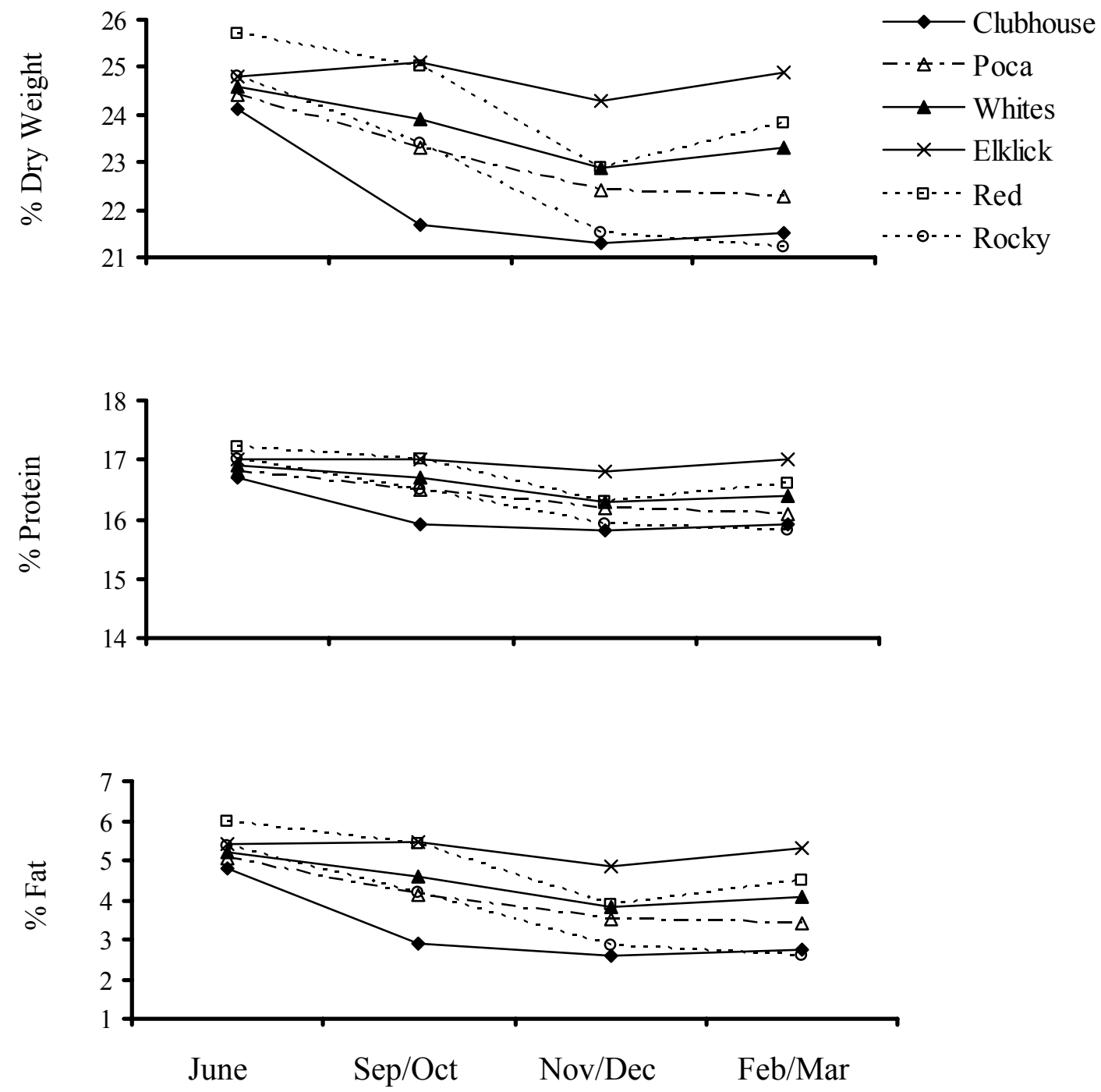

Figure 6. Seasonal mean percent proximate body composition values of brook trout greater than $130 \mathrm{~mm}$ total length for the six study sites. Note: June - November/ December sampled in 2003, and February/ March in 2004. 

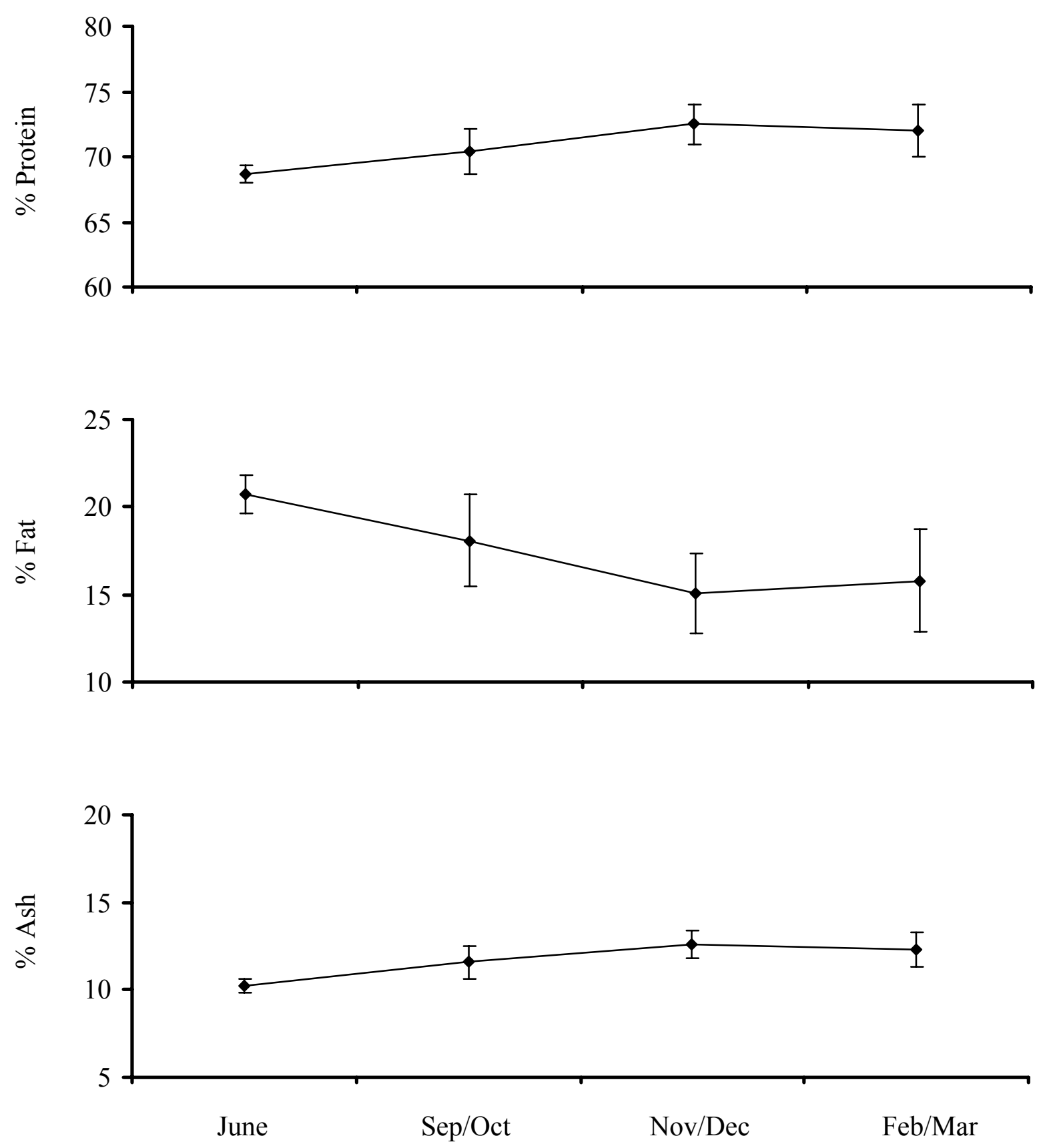

Figure 7. Seasonal mean percents of protein, fat, and ash weights of the total dry weight of brook trout greater than $130 \mathrm{~mm}$ total length (all streams combined). Note: June November/ December sampled in 2003, and February/ March in 2004. 

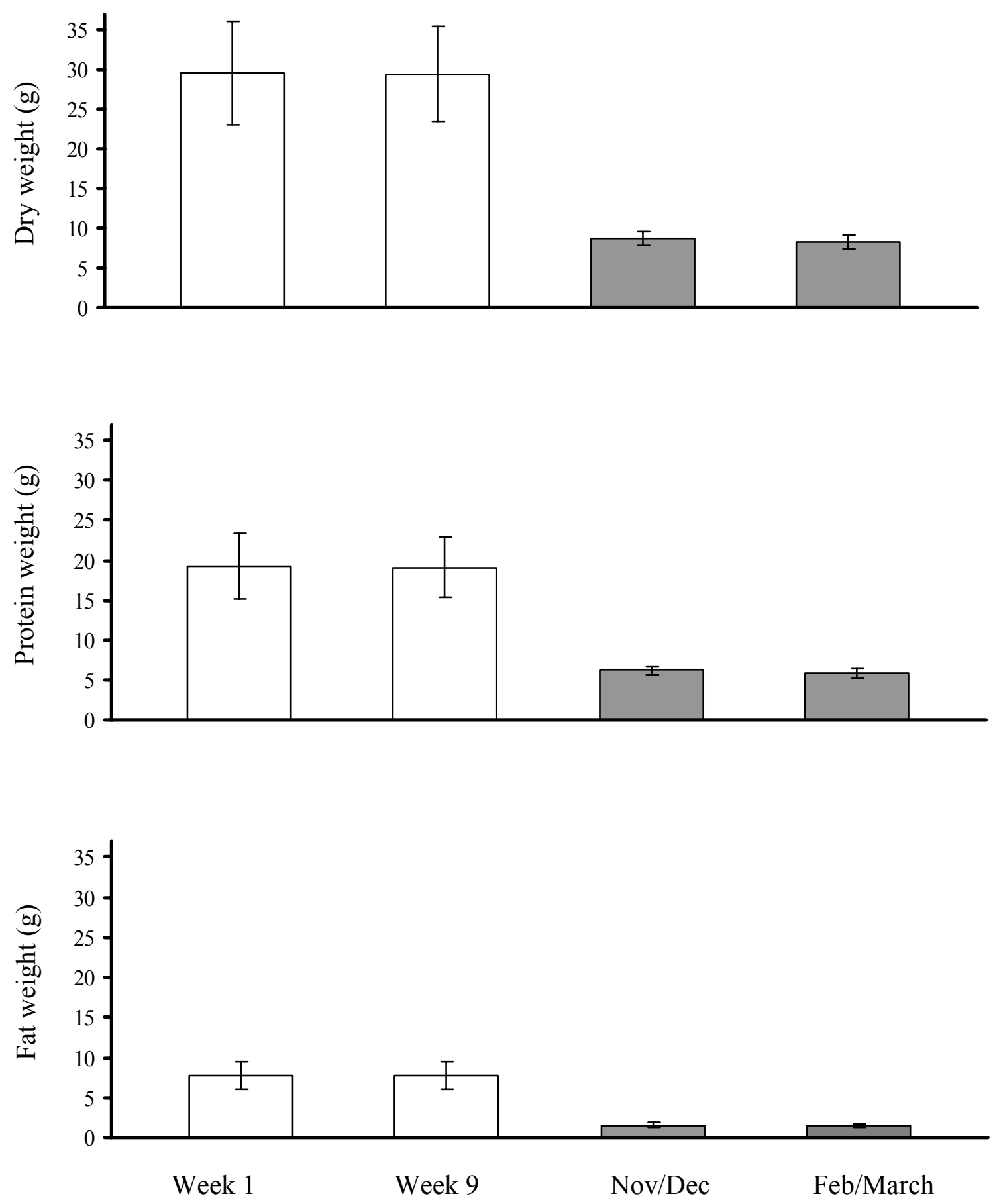

Figure 8. Means of estimated body composition weights of experimental (Week 1, Week 9) vs. wild (November/ December, February/ March) brook trout determined using Bioelectrical Impedance Analysis. Trout from all streams combined were used to calculate means of wild brook trout for the two sampling periods shown, and trout in tanks A and B were similarly combined for each week. Error bars represent $95 \%$ confidence intervals. 


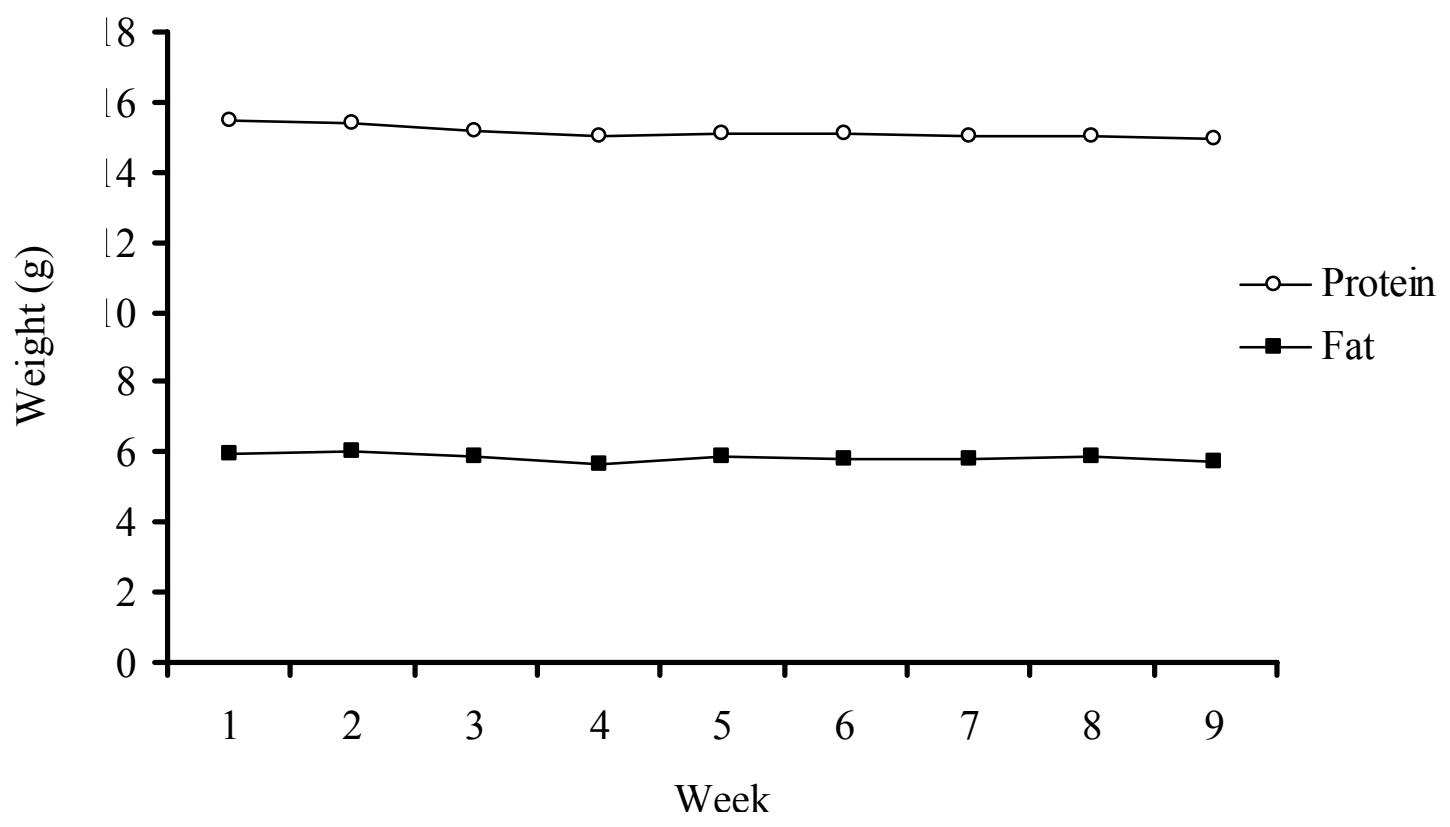

Figure 9. Means of protein and fat weights for brook trout in simulated winter experiment determined using Bioelectrical Impedance Analysis. Note: Trout in each tank were combined to generate means. 


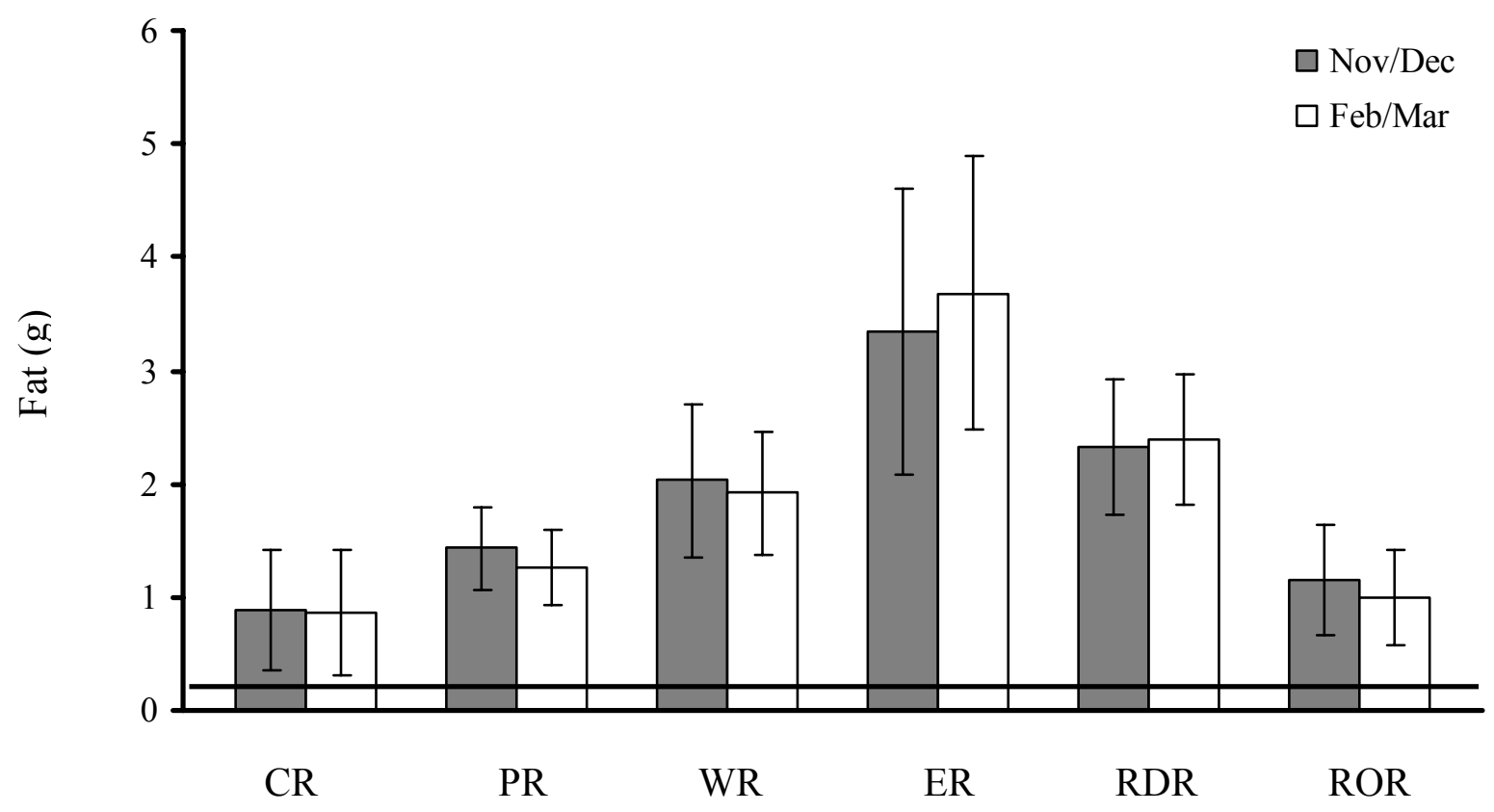

Figure 10. Mean fat weights of brook trout from pre- (November/ December) and post(February/ March) winter sampling periods. Black line represents critical level of fat ( 0.2 g) that may lead to mortality for salmonids (juvenile rainbow trout 120-142 mm TL, Oncorhynchus mykiss, Simpkins et al. 2003a). Error bars represent 95\% confidence intervals. CR - Clubhouse Run, PR - Poca Run, WR - Whites Run, ER - Elklick Run, RDR - Red Run, ROR - Rocky Run. 


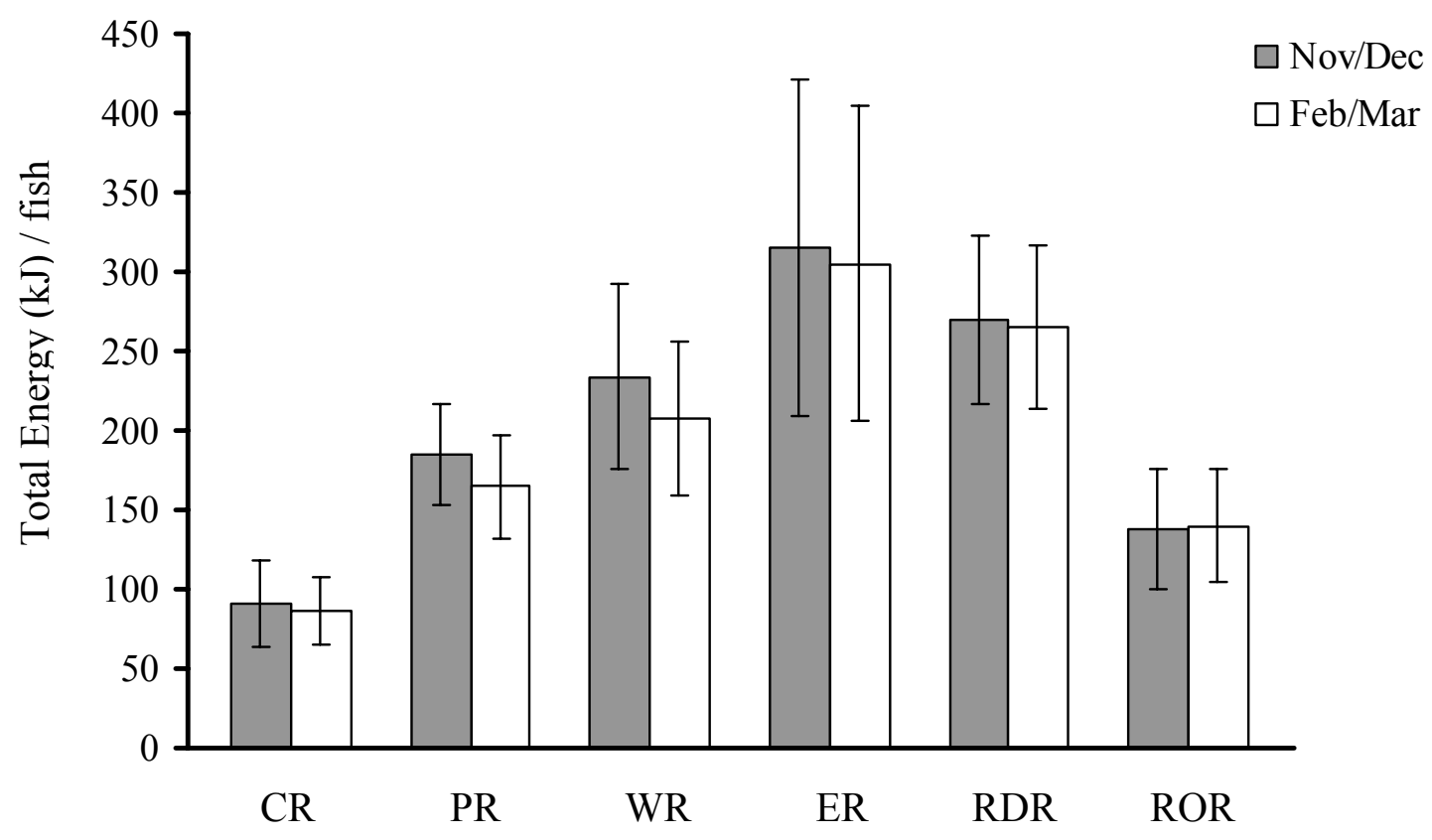

Figure 11. Mean total energy $(\mathrm{kJ})$ content of stock-size brook trout for pre- (November/ December) and post- (February/ March) winter sampling periods. Error bars represent 95\% confidence intervals. CR - Clubhouse Run, PR - Poca Run, WR - Whites Run, ER - Elklick Run, RDR - Red Run, ROR - Rocky Run. 


\title{
Chapter 3. Can Angler Harvest Affect Brook Trout Populations in West Virginia Headwater Streams?
}

\author{
Abstract \\ Angling mortality is poorly understood in headwater brook trout streams. Trout \\ exit winter with sufficient energy reserves, but spring population estimates fail to detect \\ many larger sized brook trout. Therefore, the objective of this study was to evaluate \\ whether angler harvest affects spring brook trout populations in headwater streams. We \\ used angler surveys to obtain catch estimates of native brook trout, and motion-activated \\ cameras to estimate angler effort on six headwater streams. Anglers that indicated a \\ preference for native brook trout had a mean catch of 4.5 brook trout per fishing trip. \\ Almost $76 \%$ of this group fished headwater streams, and $67 \%$ of all anglers began fishing \\ as early as late February. Native anglers also preferred keeping brook trout as small as \\ 7.1 inches on average. The cameras indicated that Elklick Run had the most fishing \\ pressure, and Whites Run had the least. Decreases in brook trout population densities \\ after winter coupled with high angler effort likely lead to a decrease in the number of \\ large brook trout present in the streams. Although the cameras likely underestimated \\ total fishing effort on streams, estimated harvest was still sufficient to account for \\ overwinter declines in large trout. Movement also likely had an effect on changes in \\ population abundance, but was not measured in this study. While the findings of our \\ study provide a base for evaluating angling effects, more research is needed to fully
}


understand the interaction between harvest and population structure of brook trout in headwater streams. 


\section{Introduction}

Brook trout (Salvelinus fontinalis) native to West Virginia often inhabit headwater streams. These streams are characterized by small mean wetted widths, high gradients, elevated dissolved oxygen concentrations, cold temperatures, and perennial water flow. Brook trout are typically the only salmonid found in these low-order systems. Though these trout may not reach large sizes typical of brown (Salmo trutta) and rainbow (Oncorhynchus mykiss) trout also found in West Virginia, they are still considered a highly sought after game fish by anglers.

Winter is considered the critical period in life for stream salmonids (Whitworth and Strange 1983). During this time a fish must consume enough energy to meet basic metabolic needs. Cunjak and Power (1986) determined that protein stores, which are only used after most of the lipid stores have been depleted (Love 1970) of arctic charr (Salvelinus alpinus) were not mobilized over winter. In addition, this population did not show any indication of the fishes approaching critical levels of reserve depletion.

Previous sampling of six streams in West Virginia has found reductions in numbers of adult brook trout following winter. This could be due to emigration, overwinter mortality, or mortality due to activities such as angling (harvesting). In the six streams in this study, data have shown that brook trout were unlikely to starve over winter in 2003-2004 (Chapter 2). Although brook trout may emigrate, movements of brook trout are generally relatively small in headwater streams in this region (Logan 2003). Therefore, it seems likely that most adult brook trout in the Central Appalachian Mountains should have sufficient energy stores to survive the winter. 
Preferential harvest of native brook trout in headwater streams is a possible mechanism for the decreased numbers of trout in early winter. Angler harvest can have several effects on fish populations. It can alter species composition, biomass, age, and size structure of fish populations (Anderson and Nehring 1984). In addition, selectively harvesting older fish can shift the population structure to younger, smaller fish (Hunt 1981). Exploitation rates of trout in Wisconsin streams ranged from $11-24 \%$, which led to fewer trout in the stream (Hunt 1981). If anglers preferentially harvest large-sized trout, then we would expect to see fewer of these individuals in the population, and preliminary data from spring surveys indicates that fewer large trout are present in these streams compared to late-fall surveys (Figure 1).

Since brook trout likely survive the winter months, then it is possible that angler harvest in late winter and early spring is depleting brook trout in these headwater systems. We found no studies evaluating the effects of angler exploitation on trout in these low-order streams, therefore our objective is to evaluate whether angler harvest can affect brook trout populations in spring in headwater streams.

\section{Study Area}

Six West Virginia streams were used in this study. Elklick Run is located in the Fernow Experimental Forest, and Red Run is a special regulations, catch-and-release only stream. Both are part of the Cheat River drainage system and located in Tucker County. Whites Run in Pendleton County, is part of the South Branch of the Potomac River Watershed. Poca Run and Clubhouse Run are part of the Greenbrier River watershed, and both are found in Pocahontas County. Rocky Run is within the MeadWestvaco Wildlife and Ecosystem Research Forest in Randolph County, and flows 
into the Middle Fork River. All streams except Rocky Run are located in the Monongahela National Forest. The forest is located within the Appalachian Plateau and is characterized by mountainous land forms.

The six sites are headwater streams $\left(1^{\text {st }}\right.$ and $2^{\text {nd }}$ order $)$, with each stream supporting naturally-reproducing brook trout populations, and are characterized by riparian vegetation made up of mixed-deciduous hardwoods. Unique features include a resevoir at the top of Elklick Run that in previous years provided drinking water for local residents, and Red and Rocky Runs are treated every year in their headwaters with limestone sand by West Virginia Division of Natural Resources to buffer against acidic waters. Mean hourly temperatures for 2003 ranged from $9.2-11.1{ }^{\circ} \mathrm{C}$ (See Figure 1 in Chapter 2) in these streams (Note: Elklick Run and Rocky Run not included due to loss of temperature loggers). Low flow can become a problem in drought years as in 2002, when several neighboring streams stopped flowing altogether.

\section{Methods}

\section{Population Abundance}

Streams were sampled four times in 2003-2004. The spring/summer sampling period occurred on $13-16$ June, the pre-spawn period on 26 September - 10 October, post-spawn on 21 November - 3 December, and the post-winter period on 25 February 10 March. To effectively sample the brook trout populations on each stream, three $100 \mathrm{~m}$ stream reaches were chosen that were representative of the habitat areas of each stream. Three pass removal using a DC-pulse backpack electrofisher was implemented to obtain 
fish population and density estimates. Block nets were used at the end of each section to limit emigration and immigration during sampling.

Upon completion of the electrofishing pass, brook trout were immediately anesthetized with $120 \mathrm{mg}$ clove oil per liter of water (Anderson et al. 1997) and the total length (TL in millimeters) and weight (grams) of each fish were measured.

Subsequently trout were placed into a live well to monitor condition before being released back into the stream. Brook trout abundances of stock-size trout $(>130 \mathrm{~mm} \mathrm{TL}$ according to Willis et al. 1993) were determined by calculating population estimates of each 100 m reach using Program 2CAPTURE (White et al.1982).

\section{Angler Impacts}

Harvest effects and demographics of anglers were estimated using angler questionnaires. The angler surveys were designed to determine demographics, type of fishing, time spent fishing, and estimated catch of trout by fishermen (Figure 2). Surveys were conducted by the researcher from 13 March - 29 May 2004. A roving design was utilized where the surveyor walked or drove along target (streams from study area) and adjacent streams (higher order streams that study streams feed into) and personally interviewed each angler encountered. Streams were randomly assigned a day and time of day (morning or afternoon) to be sampled. All anglers were asked each question on the survey, but were not required to answer any.

Angler use on headwater streams is difficult to determine accurately because it is believed that anglers who fish them do it infrequently throughout the day. As a result, we used motion activated game cameras (DeerCam ${ }^{\circledR}$ Scouting Camera) to estimate the number of fisherman on each stream. Two cameras were placed on each stream in 
optimal fishing areas, typically overlooking pools (to maximize encounters). If the same angler was seen during the same day on one or both cameras, it was counted as one encounter. Film from each camera was developed using a third-party that censored identifying features of the pictured anglers. The cameras were in operation during the same time period that anglers were being surveyed. Although angling may have taken place prior to camera placement (i.e. early winter), cameras were battery operated and were limited to periods of higher temperatures in the batteries' operating range of $>-5^{\circ} \mathrm{C}$.

To get an estimate of angler impacts on brook trout populations in headwater streams we used the simple formula:

Catch $=\mathrm{N}_{1} \mathrm{c}_{1}$, where,

$$
\begin{aligned}
& \mathrm{N}=\text { population size, } \text { or number of anglers } \\
& \mathrm{c}=\text { mean catch per trip of anglers surveyed (Pollock et al. 1994). }
\end{aligned}
$$

For our purposes the number of anglers $(\mathrm{N})$ will be the number of fisherman photographed on each stream. In this manner we can get an estimate of angler harvest and effort on each of the study streams. Angler harvest was compared to population declines in stock-sized trout over winter. To calculate the minimum number of angler surveys needed with a minimum detectable difference of 1 when comparing mean catch rates between groups, we used:

$$
\mathrm{N}=\frac{\mathrm{z} \sqrt{ } \sigma^{2}}{\mathrm{E}^{2}}
$$

where, 
$\mathrm{N}=\#$ of surveys, $\mathrm{z}=1.96(95 \%$ confidence interval $), \sigma^{2}=24.7$ (catch rate

variance), $\mathrm{E}=1.0$ (desired minimum detectable difference of the mean) (Zar

1999).

Based on this formula and a 1.0 difference in the means of catch rates, the target number of completed surveys for anglers that fished for trout was 95.

\section{Statistical Analysis}

We used a repeated-measures ANOVA and a series of contrast statements to test for differences in stock-sized brook trout population densities for each stream between pre and post winter sampling periods. Each section of the stream was used as a replicate in the analysis. Although each $100 \mathrm{~m}$ section is inherently different in habitat, each is a representation of the overall habitat variability in the stream, and therefore each section within a stream was treated as a replicate.

\section{Results}

\section{Population Abundance}

Brook trout abundances of stock-size fish were highest in all streams in the prespawn sampling period (Figure 1). Abundances then decreased, and were lowest in the spring sample. Trout at Poca Run decreased significantly $(\mathrm{P}<0.01)$, while trout at Red and Rocky Runs decreased the least from November/ December to February/ March.

\section{Angler Impacts}

A total of 96 angler interviews were completed from early March until the end of May. Interviewed fishermen could be separated into three types of anglers; "catch- 
release anglers", "stocked trout" fishermen, and "native brook trout" anglers. The first group made up 5\% of the total interviews and encompassed all anglers who said they do not keep any trout. The second type only fish larger streams for stocked trout and comprise $52 \%$ of the anglers interviewed, while the third type of fishermen made up $43 \%$ and only fish for native brook trout predominantly on smaller streams. Some overlap did occur between categories (i.e. one angler fly-fished for native trout), but any angler who harvested native trout were considered part of the third group. In addition, male anglers comprised almost $92 \%$ of the interviews.

Fly fishermen traveled the farthest on average and native fisherman the least to the target stream (Table 1). Mean hours spent fishing per day, and number of streams visited per trip were similar between all groups, but the native angler group was lowest for both. Native fishermen spent the most time fishing headwater streams (approximately $76 \%$ ); almost twice that of fly fishermen and stocked trout fishermen ( $40 \%$ and $42 \%$, respectively). Native anglers also kept smaller fish on average than stocked fishermen (7.15 and 10.6 inches, respectively). Stocked trout anglers kept an average of almost four trout per trip, while native anglers kept almost five.

Motion-activated cameras were an effective means of estimating use of headwater streams by anglers, despite some difficulties. The number of different anglers photographed during the camera survey period ranged from 1 to 16 anglers across our six study streams. Sixteen anglers were photographed at Elklick Run, and it was the highest for all streams during the sampling period (Table 2). Whites Run had only one photograph of an angler, though one of the cameras was stolen midway through the 
study. Poca Run and Clubhouse Run also had cameras stolen, although one of the Poca Run cameras photographed nine anglers.

A total catch of brook trout was estimated for each stream based on the mean number of brook trout kept per trip from the native fishermen group and the number of anglers photographed at each stream (Table 2). Catch information on this angling group was used because all of these streams only contain native brook trout, and presumably that is what the fishermen were trying to catch. Total catch was highest at Elklick Run (72 trout), and lowest at Whites Run (4.5 trout) because only one angler was encountered on film. Red Run had a high total catch (59), but this is misleading because it is a catchand-release stream, and assuming no trout were illegally harvested, the total catch would be zero.

Brook trout harvest per 100 meters was also estimated by dividing total catch by the total length of the stream in order to more easily compare catch to change in stocksize brook trout population abundance. Poca Run was highest with almost 4 brook trout every 100 meters, and Elklick Run had nearly 2 trout harvested within the same distance. Again, with only one fisherman photographed, Whites Run was lowest (0.09). There was an inverse relationship between population decline and harvest rate of stock-size brook trout (\# trout / $100 \mathrm{~m}$ ) (Figure 3).

\section{Discussion}

Based on the number of native brook trout fishermen interviewed, and the decrease in population abundance of brook trout at all streams it appears that anglers are capable of affecting brook trout populations in headwater streams. Stock-size brook trout abundance decreased from 2-20 trout per $300 \mathrm{~m}$ of stream length, and based on fat 
estimates it is unlikely that adult brook trout starved over this time period (Chapter 2).

Estimated catch per trip, and number of anglers photographed lead us to believe that there is a substantial amount of pressure on brook trout populations at the six study streams.

Population abundance in all streams decreased from early to late winter, yet brook trout did not appear to starve during this time (Chapter 2). Percent lipids increased in brook trout in nearly all streams from early to late winter, and protein stores appeared to be unaffected (except Rocky Run, Chapter 2). Love (1970) showed that these protein stores would be untouched unless lipid levels were severely depleted. In a study by Cunjak and Power (1986) brook trout populations did not approach critical resource depletion. Although our study did not account for any fishes that may have died over winter, the trout that did survive did not show any signs of approaching severe resource depletion. Therefore, the decrease over winter in adult brook trout is likely related to movement of fishes, or angler harvest.

Movement of brook trout must be considered as a possible factor affecting changes in population abundance of brook trout in headwater streams. Movement enables fishes to respond to physiological and outside stressors present in the stream environment to increase growth, survival, and reproductive success (Kahler et al. 2001). Studies have shown that resident stream fish may move little out of their home ranges, especially during non-spawning months (Adams et al. 2000, Cargill 1980, Clapp et al. 1990, Rodriguez 2002, Solomon and Templeton 1976), but other studies attest that stream fish are highly mobile (Gowan and Fausch 1996). Regardless, it appears brook trout are more likely to be mobile than other stream salmonids (Rodriguez 2002). In addition, there can be a difference in amount of movement between adult and sub-adult 
individuals. This study focused on adult brook trout which, if like other adult salmonids, show more restricted movement due to defending local territories (Rodriguez 2002). While, it is important to note that changes in population abundance in the study streams can be attributed to seasonal movement, we do not believe it to be significant in these streams.

Over the summer, abundance of stock-size brook trout increased in all streams except Whites and Rocky Runs. This increase is likely due to adult brook trout moving into the upper reaches of these headwater streams to spawn. It is highly unlikely that juvenile recruitment was a factor because growth was likely not great enough in the summer months for juvenile trout to move into the adult size class. From the pre- to postspawning sampling periods we recorded a decrease in population abundance of adult trout at all streams. We don't predict that spawning mortality was high because fish did not appear to starve when they were sampled in November/ December (Chapter 2). Therefore, it may be likely that trout moved out of the system after spawning for better overwinter habitat, decreased ice flow, and more refugia from winter conditions. Trout also may have emigrated because it has been shown that predation on spawning fish may occur more frequently in lower water flows (Schmetterling 2001) as is typical this time of year in headwater streams. Other brook trout populations have also shown major postspawn downstream movement during this time of year (Curry et al. 2002). In addition, during winter, trout will more often use deeper pool habitats as refugia (Curry et al. 2002, Dare 2002), which may be more available in larger systems. The amount of crowding in headwater streams may also affect brook trout movements. Matthews et al. (2001) 
concluded that density-dependent effects led to increased downstream movement prior to winter due to crowding and may indirectly lead to overwinter mortality.

Winter conditions also dictate movements of stream salmonids. Again, adult brook trout abundance decreased in all streams in this study over winter. We have previously shown that brook trout do not starve during this time of year, so natural mortality is not a likely factor for the decrease, but movement of fishes out of the sampled stream reaches might be a likely factor. Emigration may have led to the lower abundances of trout seen in the study streams. Although in this region, brook trout spawn in September and October, adult trout could have still been emigrating from the system after the November/ December sampling period because they may have spawned at a later time. Though we expect increased immigration to occur in spring, it may not have started by our sampling period because flows had not been sufficient to facilitate major movements. Salmonids often increase movements during higher flows (Swanberg 1997), and are more likely to move at the rising limb and peak of a hydrograph (Schmetterling 2001). Perceived mortality of adult brook trout over winter may also be related to angling pressure.

It is difficult to assess how much of a role movement plays in brook trout population changes over winter in headwater streams, but this study did attempt to analyze the effect of angler harvest. Strong relationships were found between estimated harvest rate and observed declines in stock-size brook trout in streams over winter. At minimal harvest $(<1$ trout $/ 100 \mathrm{~m})$ adult brook trout populations declined from $13 \%$ to $31 \%$. Elklick Run had a low population decline ( $\sim$ fish / 100m, or $12.5 \%$ ), but harvest was second-highest (1.71 trout / 100 m) of all streams. Similarly, Poca Run had the 
highest recorded harvest, but the lowest population decline. This inverse relationship between harvest and population decline is likely a result of underestimated harvest at all streams because of camera placement, or due to angling occurring prior to camera placement.

Anglers were grouped into 3 distinct types based on angler interviews. This was expected because angler interviews took place at a special regulations, catch-and-release only stream (Red Run), recently stocked streams, and occasionally $(\mathrm{N}=8)$ on headwater streams only supporting native brook trout. Though all may be important for various reasons, for this discussion we will focus on the native angler group because these are the anglers affecting brook trout in headwater streams.

Native anglers tend to fish more locally (traveled the least miles to target stream); therefore it is likely that they will fish these headwater streams rather frequently. In fact several anglers that travel small distances communicated that they frequently "like to hit up" the same stream over several years. Local anglers have been found to be a major component of angler catch in other systems (Nielsen et al. 1980). In addition, this group of anglers tends to keep more trout. This can have a major impact: if anglers are taking 4.5 brook trout per trip, and they are more frequently visiting these headwater streams, the fishery may become denuded over a short period of time. Densities in these streams range from only $2-15$ stock-size brook trout $(\geq 130 \mathrm{~mm} \mathrm{TL})$ per $100 \mathrm{~m}^{2}$, and almost $76 \%$ of this angler group responded that they fish headwater streams, further demonstrating the sensitivity of these headwater streams.

Another important aspect of the native angler group is that they tend to keep smaller brook trout. The mean minimum size kept of anglers interviewed in this study 
was 7.15 inches $(181.6 \mathrm{~mm})$. This is likely a result of brook trout in headwater streams historically being smaller in size, but it could also be a function of long-term angling pressure on these streams. For example, Poca Run has the 2 nd highest angling pressure (excluding Red Run) according to camera intercepts, and it had only 8 brook trout / 100 $\mathrm{m}^{2}$ over $200 \mathrm{~mm}$ total length (TL) during the pre-spawn sample when numbers of large trout are expected to be at their highest. As mentioned earlier, Elklick Run had the most angling pressure, and over its three stream reaches only 5 trout over $200 \mathrm{~mm}$ (TL) were found. The maximum number of these larger brook trout in each stream is likely a function of carrying capacity, and angler harvest may be holding populations in these streams well below it. If anglers are preferentially harvesting trout over 7 inches, then that will likely limit trout growing to a larger size. It is apparent that anglers have a significant impact on size and densities of brook trout in headwater streams, but the timing of their harvest may be just as important.

Almost $67 \%$ of anglers interviewed began fishing before the end of February. If this is consistent with the native angler group, then it is reasonable to assume that many of the larger fish are being taken out of the larger streams where trout are overwintering, or the study streams early in the year when they are depleted in energy stores, and possibly easier to catch. Since anglers in West Virginia can harvest year round (no closed season), the first late winter thaw may be the first opportunity for anglers to catch trout. According to temperature data for some of the streams the first major thaws occurred in late January, and again in mid-February. Therefore, late January or midFebruary may be considered an unofficial "opening day" to the fishing season. This is important considering opening days have been found to be a time of increased catch that 
is higher than normal (Nielsen et al. 1980). Such a heavy harvest in these smaller systems could explain why larger brook trout seem to disappear over winter in these headwater streams.

Movement and harvest together may also cause brook trout populations to decrease over winter. If brook trout are moving out of the system into larger streams for better winter refugia, they are still vulnerable to anglers. In essence, native brook trout moving to a stream that is inhabited by stocked trout will likely be assailed by members of the stocked trout type of angler. Therefore, this may be a major factor for the decrease in adult brook trout populations over winter; however we could not confirm this because it was unreasonable to ask if these anglers were harvesting native trout in the stocked streams because of the inherent bias of the angler not knowing the difference between a stocked and native brook trout. Still, angler harvest may be significant on native brook trout that spend most of their lives in headwater streams.

Limitations of sampling design likely contributed to an underestimation of the amount of fishing effort on each stream. Only two cameras were placed on each stream where we thought the highest numbers of anglers would be encountered. This was entirely subjective, and substantially more anglers may be using each stream than what the cameras photographed. Whites Run provides a good indication of this theory: It had the least number of anglers recorded, probably for two reasons. One of the cameras was stolen and this camera photographed at least one angler because this researcher observed this occurrence. In addition, this stream had a gravel road along its entire length, thereby considerably increasing the number of access points to the stream. A camera was also stolen at Clubhouse Run, and likely led to an underestimation of angler effort. 
Limitations of the cameras, due to batteries only working properly in warmer weather ( $>$ $-5^{\circ} \mathrm{C}$ ) prevented us from recording angler effort during thaw events in late winter, further leading to underestimates of actual angler catch. Despite these caveats, and although we possibly underestimated angler catch, this study shows the significance of angler effort on headwater streams.

This study has previously shown that brook trout do not appear to starve over winter (Chapter 2), yet large trout appear to be lower in abundance in these streams in the spring. According to interviews, a large percentage of anglers begin fishing well before the spring months. In addition, those who only fish for native brook trout are more likely to harvest more trout at smaller sizes in these headwater streams. Movement is also a possible factor because trout use larger systems for refugia to winter conditions, and many brook trout may have emigrated to these habitats in this season in adjacent systems. In addition, it is difficult to determine if these fish had immigrated back into the system previous to the spring sampling period. The predominantly small size of brook trout in headwater streams in this study may reflect historically high angler harvest of native brook trout. In addition, longer-lived adult brook trout may be rare in these headwater streams because they move out of the system due to greater competition in smaller streams.

To understand the population dynamics of resident stream fish, managers must consider factors outside of the usual biological reasons (emigration, immigration, predation, etc.). Anglers can have a major impact on sensitive fishes in small systems because they can cull fishes from headwater streams and the larger streams that serve as a refuge to harsh winter conditions. Special regulations present on one stream may not be 
effective because trout may move to another system to be culled by anglers (Gowan et al. 1994). With more research the complex interactions between anglers, movement, and brook trout in headwater streams may better explain why these populations often decrease over winter. 


\section{Literature Cited}

Adams, S. B., C. A. Frissell, and B. E. Rieman. 2000. Movements of nonnative brook trout in relation to stream channel slope. Transactions of the American Fisheries Society 129: 623-638.

Anderson, R. M. and R. B. Nehring. 1984. Effects of a catch-and-release regulation on a wild trout population in Colorado and its acceptance by anglers. North American Journal of Fisheries Management 4: 257-265.

Anderson, W. G., R. S. McKinley, and M. Colavecchia. 1997. The use of clove oil as an anesthetic for rainbow trout and its effects on swimming performance. North American Journal of Fisheries Management 17, 301-307.

Cargill, A. S. 1980. Lack of rainbow trout movement in a small stream. Transactions of the American Fisheries Society 109: 484-490.

Clapp, D. F., R. D. Clark, and J. S. Diana. 1990. Range, activity, and habitat of large, free-ranging brown trout in a Michigan stream. Transactions of the American Fisheries Society 119: 1022-1034.

Curry, R. A., D. Sparks, and J. Van de Sande. 2002. Spatial and temporal movements of a riverine brook trout population. Transactions of the American Fisheries Society 131: 551-560.

Cunjak, R. A. and G. Power. 1986. Seasonal changes in the physiology of brook trout, Salvelinus fontinalis (Mitchill), in a sub-Arctic river system. Journal of Fish Biology 29: 279-288.

Dare, M. R. and W. A. Hubert. 2002. Changes in habitat availability and habitat use and movements by two trout species in response to declining discharge in a regulated river during winter. North American Journal of Fisheries Management 22: 917928.

Gowan, C., M. K. Young, K. D. Fausch, and S. C. Riley. Restricted movement in resident stream salmonids: a paradigm lost? Canadian Journal of Fisheries and Aquatic Sciences 51: 2626-2637.

Gowan, C. and Fausch, K. D. 1996. Mobile brook trout in two high-elevation Colorado streams: re-evaluating the concept of restricted movement. Canadian Journal of Fisheries and Aquatic Sciences 53: 1370-1381.

Hunt, R. L. 1981. Population dynamics of wild brown trout and associated sport fisheries in four central Wisconsin streams. Wisconsin Department of Natural Resources Technical Bulletin 121: 1-22. 
Kahler, T. H., P. Roni, and T. P. Quinn. 2001. Summer movement and growth of juvenile anadromous salmonids in small western Washington streams. Canadian Journal of Fisheries and Aquatic Sciences 58: 1947-1956.

Keading, L. R. 1980. Observations on communities of brook and brown trout separated by an upstream-movement barrier on the Firehole River. Progressive Fish Culturist 42: 174-176.

Logan, M. N. 2003. Brook trout (Salvelinus fontinalis) movement and habitat use in a headwater stream of the Central Appalachian Mountains of West Virginia. Master's Thesis. 1-63.

Love, R. M. 1970. The chemical biology of fishes. Academic Press. London.

Matthews, W. J., K. B. Gido, and E. Marsh-Matthews. 2001. Density-dependent overwinter survival and growth of red shiners from a southwestern river. Transactions of the American Fisheries Society 130: 478-488.

Nielsen, L. A., W. T. Kendall, and L. A. Helfrich. 1980. Comparison of angler use and characteristics at three catchable trout fisheries in Virginia. Proceedings of the Southeastern Association of Fish and Wildlife Agencies 34: 330-340.

Pollock, K. H., C. M. Jones, and T. L. Brown. Effort and catch estimation. Pages 213254 in Angler Survey Methods and Their Applications in Fisheries Management. American Fisheries Society, Bethesda, Maryland.

Rodriguez, M. A. 2002. Restricted movement in stream fish: the paradigm is incomplete, not lost. Ecology 83:1-13.

Schmetterling, D. A. 2001. Seasonal movements of fluvial westslope cutthroat trout in the Blackfoot River Drainage, Montana. North American Journal of Fisheries Management 21: 507-520.

Solomon, D. J. and R. G. Templeton. 1976. Movements of brown trout Salmo trutta L. in a chalk stream. Journal of Fish Biology 9: 411-423.

Swanberg, T. R. 1997. Movements and habitat use of fluvial bull trout in the Blackfoot River, Montana. Transactions of the American Fisheries Society :735-746.

White, G. C., D. R. Anderson, K. P. Burnham, and D. L. Otis. 1982. Capture-recapture and removal methods for sampling closed populations. Los Alamos National Laboratory LA-8787-NERP. 235 pages.

Whitworth, W. E. and R. J. Strange. 1983. Growth and production of sympatric brook trout and rainbow trout in an Appalachian stream. Transactions of the American Fisheries Society 112: 469-475.

Willis, D. W., B. R. Murphy, and C. S. Guy. 1993. Stock density indices: development, 
use, and limitations. Pages 447-481 in Fisheries Techniques. American Fisheries Society, Bethesda, Maryland.

Zar, J. H. 1999. Biostatistical Analysis. $4^{\text {th }}$ Edition. Prentice Hall, Inc., Upper Saddle River, New Jersey. 
Table 1. Averages of answers to select questions from angler surveys. Note: Standard error of each mean shown in parentheses. \% anglers fishing headwater streams are actual proportions.

\section{Type of Angler}

Fly fisherman / No catch

Number interviewed

Distance Traveled (miles)

Hours / day spent fishing

\# trips / year

\# streams / trip

$\%$ that fish headwater streams

Minimum size kept (inches)

\# trout kept per trip
5

$192(85.9)$

$7.40(1.12)$

$65.2(34.7)$

$3(0.84)$

40.0

0
Stocked trout angler

50

$92.2(10.5)$

$7.48(0.39)$

$21.7(4.96)$

$2.64(0.17)$

42.0

$10.6(0.53)$

$3.65(0.54)$
Native fisherman

41

$45.7(11.3)$

$5.37(0.55)$

$25.8(5.38)$

$2.63(0.27)$

75.6

$7.15(0.54)$

$4.5(0.43)$ 
Table 2. Estimated brook trout catch for each stream based on the number of anglers photographed. Total catch calculated by multiplying number of anglers by the mean brook trout caught per trip of native fishermen based on angler surveys. Catch per 100 meters determined by dividing total catch by total stream length.

\begin{tabular}{cccc}
\hline Stream & $\begin{array}{c}\text { Number of } \\
\text { Anglers }\end{array}$ & $\begin{array}{c}\text { Total } \\
\text { Catch }\end{array}$ & $\begin{array}{c}\text { Catch / 100 } \\
\mathrm{m}\end{array}$ \\
\hline $\begin{array}{c}\text { Clubhouse } \\
\text { Run }\end{array}$ & 3 & 13.5 & 0.54 \\
Poca Run & 9 & 40.5 & 3.68 \\
Whites Run & 1 & 4.50 & 0.09 \\
Elklick Run & 16 & 72.0 & 1.71 \\
Red Run * & 13 & $58.5 *$ & $1.30 *$ \\
Rocky Run & 5 & 22.5 & 0.38 \\
\hline
\end{tabular}

* Red Run is a special regulations stream in which all trout must be released, so the estimate here is catch whereas for the other streams it is assumed to be an estimate of harvest. 


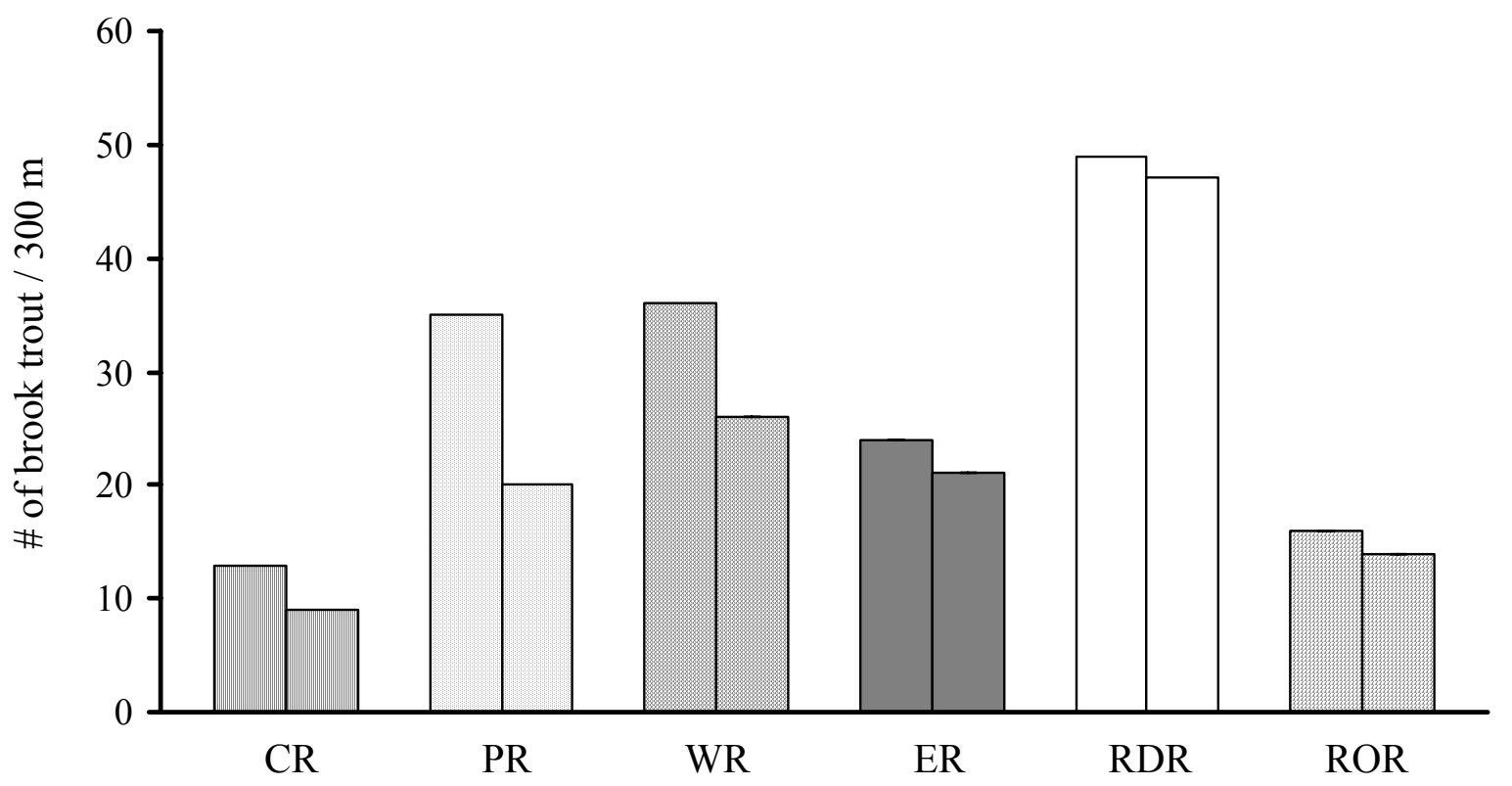

Figure 1. Changes in brook trout population abundances over winter of stock-size ( $>130$ $\mathrm{mm}$ TL) trout as calculated by Program 2CAPTURE. Note: The first histogram of each pair was sampled in November/ December 2003 and the second in February/March 2004. CR - Clubhouse Run, PR - Poca Run, WR - Whites Run, ER - Elklick Run, RDR - Red Run, ROR - Rocky Run. 


\section{Angler Questionnaire}

Interview \#

Stream

Date
Road Crossing _

Age Group (Years) $\quad<18 \quad 18-29 \quad 30-39 \quad 40-49 \quad 50-64 \quad 65$ and over

Gender $\quad \mathrm{M} \quad \mathrm{F} \quad$ Race

Distance traveled to fishing site

Fishing method $\quad$ Rod \& Reel Fly-fishing Type of Bait

Total hours spent

Typical fishing times

Catch Data

Q1. Do you ever keep the trout that you catch?

Q2. Do you keep native brook trout?

Q3. What is the minimum size you keep?

Q3a. Is that for stocked or native trout?

Q4. Is there a maximum size you keep?

Q5. Do you fish stocked trout waters?

Q6. Do you fish headwater (smaller streams) for brook trout?

Q7. What are the names of these smaller streams?

Q8. How many brook trout per year do you keep from an individual stream?

Q9. Which streams are these from?

Q10. How many streams do you fish per trip?

Q10a. How many brook trout do you keep per fishing trip?

Q10b. How many trips do you take per year?

Q11. How long have you been fishing today?

Q12. What month do you typically start fishing?

Figure 2. Example of angler questionnaire asked of all 96 anglers in this study. 


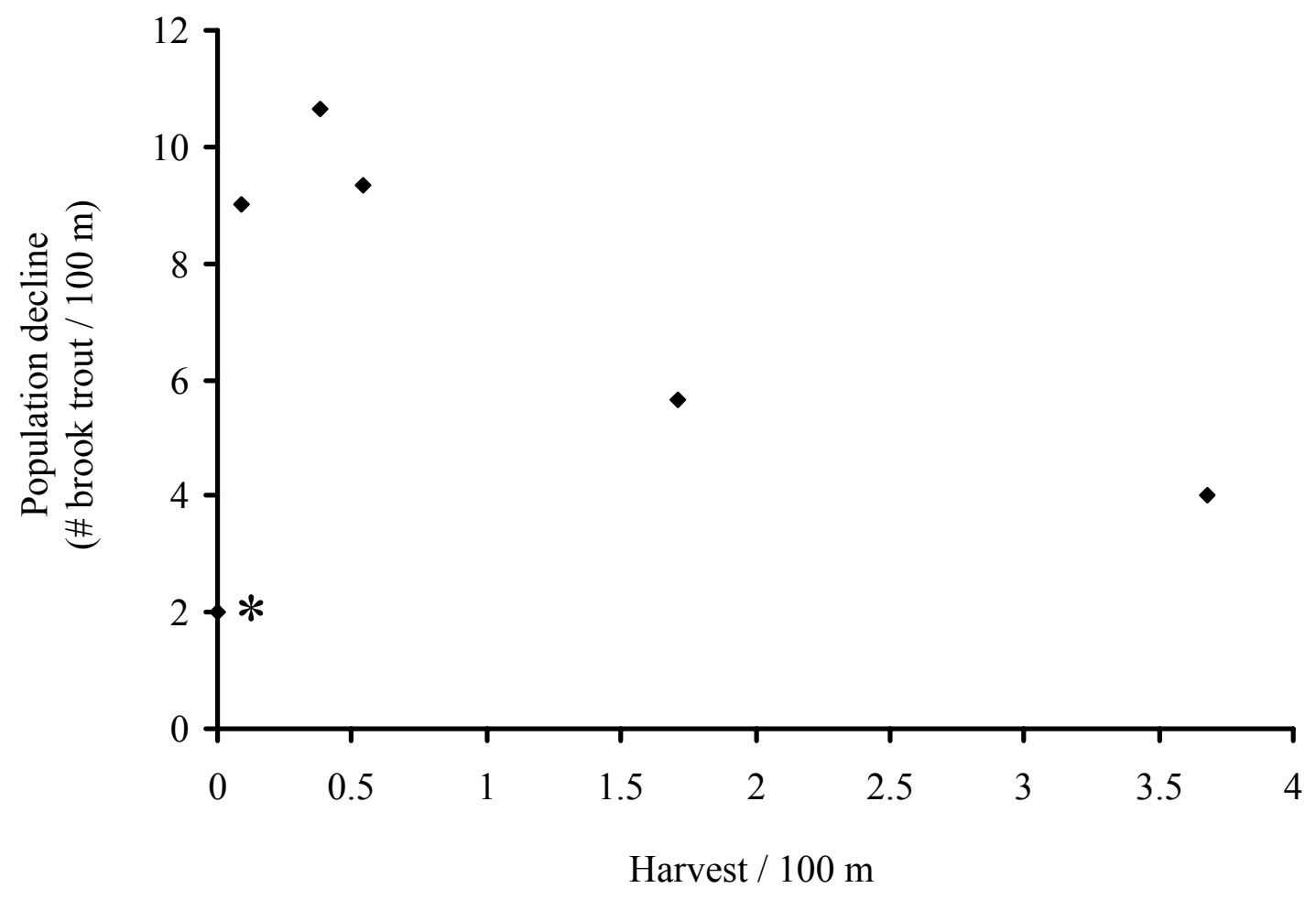

Figure 3. Relationship between population decline in the number of stock-size brook trout from post-spawning (November/ December) to spring (February/ March) and harvest (\# of brook trout kept by anglers) per $100 \mathrm{~m}$ of stream. * Red Run is a special regulations, catch-and-release only stream and harvest is assumed to be zero. 